\title{
Türkiye'de Suriyeli Mültecilere Yönelik Toplumsal Olayların Dağılımı
}

\section{Distribution of Waves of Protest against the Syrian Refugees in Turkey}

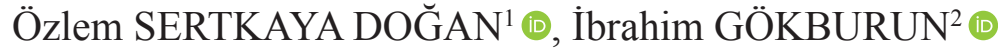

${ }^{1}$ Prof. Dr. İstanbul Üniversitesi, Edebiyat Fakültesi Coğrafya Bölümü, İstanbul, Türkiye

${ }^{2}$ Dr. Öğr. Üyesi, Pamukkale Üniversitesi, Fen Edebiyat Fakültesi, Coğrafya Bölümü, Denizli, Türkiye

ORCID: Ö.S.D. 0000-0001-7435-626X; İ.G. 0000-0003-3007-0010

\section{öz}

Türkiye'de bulunan Suriyeli mülteciler; ülkenin temel konularından birini oluşturmaktadır. Özellikle bazı illerde Suriyeli mülteciler ile ev sahibi halk arasında zaman zaman yaşanan "toplumsal olaylar" kaygı veren sonuçlar doğurmaktadır. Göç olgusunun önemli sonuçlardan biri de toplumsal olaylardır. İki ya da daha fazla kişinin belirli bir amaçla gerçekleştirdiği toplu aktiviteler şeklinde tanımlanan toplumsal olay; sosyal yaşamı doğrudan etkileyen önemli vakalardır. Bugüne kadar Suriyeli mülteciler konusunu irdeleyen birçok çalışmanın yapıldığı görülmektedir. Ancak, bu çalışmalar içinde, ev sahibi halk ile Suriyeli mülteciler arasında zaman zaman yaşanan "toplumsal olaylar" konusunu irdeleyen araştırmaların oldukça sınırlı kaldığı görülmektedir.

Bu çalışmada, Türkiye'de bulunan Suriyeli mülteciler ile ev sahibi halk arasında yaşanan toplumsal olayların dağılımının zaman ve mekân perspektifinde ortaya konulması amaçlanmıştır. Çalışmanın doğası gereği, nitel araştırma yöntemleri arasında yer alan doküman analizi tekniği kullanılmıştır. Suriyeli mültecilerle ilgili basında yer alan "toplumsal olay"konulu haberler çalışmanın temel veri kaynağını oluşturmaktadır. Sonuç olarak, 2011-2020 yılları arasında, konusu Suriyeli mülteciler olan toplumsal olaylara ilişkin niceliksel ve mekânsal bir durum tespiti yapılmıştır. Türkiye'de bulunan Suriyeli mültecilerin sayısının artmasına rağmen toplumsal olay sayısının düştüğü tespit edilmiştir. Göç konusunda Türkiye'de uygulanan politikalar, organizasyon ve kriz yönetimi açısından başarılı bir sonuç ortaya konulmuştur denilebilir.

Anahtar kelimeler: Göç, Türkiye, Suriyeli, Mülteci, Toplumsal Olay

\section{ABSTRACT}

Syrian refugees in Turkey constitute one of the crucial subjects in the country. One of the important consequences of the phenomenon of migration is social incidents. In certain Turkish cities, social incidents between refugees and local people had occasional distressing consequences. Social incidents, defined as the collective activities carried out by two or more people for a specific purpose, are critical cases that directly affect social life. It is seen that many studies have been carried out on the issue of refugees. However, studies that examine the issue of "social incidents," which occurred occasionally between the local population and refugees, are quite limited. This paper aims to show the distribution of social incidents in terms of time and place, which took place between local people and refugees. Document analysis technique, one of the qualitative research methods, was used in the study. News on "social incident" about Syrian refugees constitute the main data source of the study. As a result, a quantitative and spatial situation assessment was created and related to social incidents between 2011 and 2020. Despite the increasing number of refugees in Turkey, it was found that there was a decrease in the number of social incidents. We can contend that the Turkish Government achieved a successful result on immigration concerning crisis management and organizational ability.

Keywords: Migration, Turkey, Syrian Refugees, Waves of Protest

Başvuru/Submitted: 14.01.2021 • Revizyon Talebi/Revision Requested: 10.01.2021 • Son Revizyon/Last Revision Received: 07.05 .2021 • Kabul/Accepted: 25.10 .2021

Sorumlu yazar/Corresponding author: Özlem SERTKAYA DOĞAN / srtkydgn@istanbul.edu.tr Atıf/Citation: Sertkaya Dogan, O., \& Gokburun, I. (2021). Türkiye'de Suriyeli mültecilere yönelik toplumsal olayların dağııımı. Cografya Dergisi, 43, 37-53. https://doi.org/10.26650/JGEOG2021-861525 


\section{EXTENDED ABSTRACT}

Due to driving factors, such as internal conflicts, wars, and natural disasters in different parts of the world, thousands of people migrate to more appealing places every year. Economically developed cities with better education, health, transportation, security, and sociocultural opportunities constitute the center of attraction for migrations. Workforces, production, and cultural mobility in underdeveloped cities also cause challenging social problems that drive emigration.

Incidents that started in Syria turned into a civil war with numerous actors in a short period of time. People had to emigrate to different parts of the country and go abroad en masse for life security. As a result, Turkey applied an "open door" policy to Syrians. As of June 2020, 591,892 Syrians have emigrated and are now living in Turkey. While 2\% of Syrian refugees are staying in temporary accommodation centers, $98 \%$ live in 81 provinces by their own means.

Syrian refugees in Turkey constitute one of the major problems of the country, in terms of migration and urbanization. Especially in some cities, "social incidents" between Syrian asylum seekers and local Turkish people had occasional consequences. Waves of protest, defined as collective activities carried out by two or more people for a specific purpose, are critical cases that affect urban life. This paper aims to reveal the distribution of waves of protest, in terms of time and place, which took place between local Turkish people and Syrian refugees.

Document analysis method, one of the qualitative research methods, was used in the study. News on "social incident" about refugees constitute the main data source of the study. "News Classification and Coding Form," prepared by the researchers was created for the compilation and analysis of the data. In the form, which were categorized into six different titles - the name of the newspaper, the title of the news, the location of the news, the history of the news, the subject of the news, the source address from which the news was retrieved - were included. The scope of the study was determined to be newspapers published in Turkey; however, this made the scope very wide, making it difficult to analyze all such newspapers. In the end, two different newspapers were chosen as research samples.

Within the scope of the prepared guide form, online news was scanned using key words, such as "Syrian refugees, Syrian asylum seekers, dangerous tension, and Syrian neighborhoods." News between 01.03.2011 and 30.06.2020 was filtered and the news on the subject of "social incident" was pinpointed and archived by scanning and coding according to each title in the form. News that does not contain "social incidents" between Syrian refugees and the local population was eliminated.

Data on the dependent variable of the study were elaborated by scanning the news on the newspaper websites and compiling "the number of waves of protest against Syrian refugees." Therefore, the reliability and validity of the findings revealed in the study depend on the reliability and validity of the news in the newspapers. The study is of particular importance because it is the first to reveal the number and geographical distribution of the waves of protest that occurred between 2011 and 2020 among the local Turkish population and Syrian refugees.

Between March 2011 and July 2020, there was a total of 186 waves of protest in different Turkish cities. There were 43 waves of protest in 2017, when the most incidents per year occurred. While the number of Syrian refugees in Turkey in 2017 was 3,426,786, it increased in 2018 to 3,623,192. Although the number of refugees increased, the number of incidents fell by $63 \%$. Compared to 2017, the number of waves of protest related to Syrian asylum seekers decreased by $52 \%$ in 2019 . This is quite a significant outcome in terms of the Turkish Government immigration policy. In the first half of 2020, only five incidents occurred, but as previously emphasized, the pandemic may have affected the data.

News on "social incident" about Syrian refugees constitute the main data source of the study. As a result, a quantitative and spatial situation assessment was created regarding the waves of protest related to Syrian refugees between 2011 and 2020. Despite the increasing number of Syrian refugees in Turkey, it was found that there was a decrease in the number of social incidents. We can say that the Turkish Government achieved a successful result on immigration concerning crisis management and organizational ability. 


\section{GİRIŞ}

Dünyanın farklı yerlerinde yaşanan iç çatışmalar, savaşlar ve doğal afetler gibi itici faktörler nedeniyle, her yll binlerce insan, çekici faktöre sahip olan yerlere göç etmektedir. Ekonomik olarak gelişmiş, ulaşım, güvenlik sağlık, eğitim ve sosyokültürel imkânları daha iyi olan yerler; göçlerin çekim merkezi olmaktadır. İş gücü, üretim, tüketim ve kültürel bir hareketlilik sağlayan göçler; aynı zamanda sosyal yaşamı olumsuz etkileyen birçok sorunun kaynağını oluşturmaktadır.

İnsanlığın tarihi kadar uzun bir serüvene sahip olan göç, toplumları derinden etkilemektedir. Dünya üzerinde doğal afetler, iklim şartları, açlık, yokluk ve savaş gibi sebeplerle yüzyıllardır devam eden bir sosyal hareketlik yaşanmaktadır. Genellikle müreffeh ve güvenli bir yaşam için gönüllü olarak gerçekleşen göçler; bazı dönemlerde bir mecburiyet neticesinde yapılmaktadır. Günümüz dünyasında yaşanan iç çatışmalar, insan hakları ihlalleri, siyasi baskılar, nüfus artışı, kaynakların yetersizliği veya daha iyi yaşam olanaklarına ulaşma çabası göçlerin boyutunu giderek arttırmıştır. Özellikle can güvenliğinin sağlanması amacıyla savaş ve iç çatışmaların yaşandığı ülkelerde, insanlar bulundukları yerleri terk edip başka bir yere göç etmektedir. $\mathrm{Bu}$ göçler, birdenbire ve büyük kitleler şeklinde gerçekleştiği için varış noktasında büyük sorunlara yol açmaktadır.

'Arap Baharı' adıyla bilinen süreç, birçok Ortadoğu ve Kuzey Afrika ülkesinde kaos ve iç savaşa neden oldu. 2010 yılı sonlarında başlayan 'Arap Baharı' Suriye'de toplumsal olaylara yol açtı. 15 Mart 2011 tarihinde, Suriye'nin Dera şehrinde başlayan protestolar ve meşru hak talepleri; rejim kuvvetlerince kanlı bir şekilde bastırıldı. Göstericilere doğrudan ateşli silahlarla müdahale edilmesi ülkede farklı gruplar arasında çatışmalara neden oldu. Hızla yayılan bu çatışmalar, kısa sürede sayısız aktörü olan bir iç savaşa dönüştü. Savaş ortamında yaşanan can kayıpları, Suriyelileri güvenli yaşam alanları aramaya ve yaşadıkları yerleri terk etmeye zorladı. Halk, can güvenliği için ülke içinde farklı bölgelere ya da komşu ülkelere kitleler halinde göç etmeye başladı. Yerinden edilmiş milyonlarca Suriyeli ${ }^{1}$ evsiz ve yurtsuz kaldı. Büyük bir yıkımın yaşandığı Suriye'den dışarıya yönelen bu göçlerden en çok etkilenen ülke Türkiye olmuştur. Bu durum için coğrafyanın yakınlık ilkesinin mecburi bir sonucu denebilir. "Her şey her şeyle ilişkilidir; fakat yakındakiler uzaktakilere göre birbiriyle daha fazla ilişki içerisindedir" (Tobler, 1970, s.236-237). Tobler'in bu ifadesi Türkiye'nin Suriye'de yaşanan savaştan neden en çok etkilenen ülke olduğuna açıklık getiren bir perspektif sunmaktadır. Ancak Türkiye'nin göç tarihine bakıldığında Suriyelilerin göç süreci, bugüne kadar Türkiye'ye yönelik göçlerden nicelik ve nitelik olarak oldukça farklıdır. Çünkü 2011-2020 sürecinde Suriye'den Türkiye'ye yönelik göçlerin sayısı, daha önce yaşanan göçlerle kıyaslandığında çok yüksek bir oranla karşılaşılmaktadır.

2011-2020 döneminde Türkiye'de bulunan Suriyeli mültecilerin sayısının 3588054 kişiyi aştığı açıklanmıştır (Şekil 1). 1923-1960 y1lları arası Balkanlar'dan Türkiye’ye yönelik

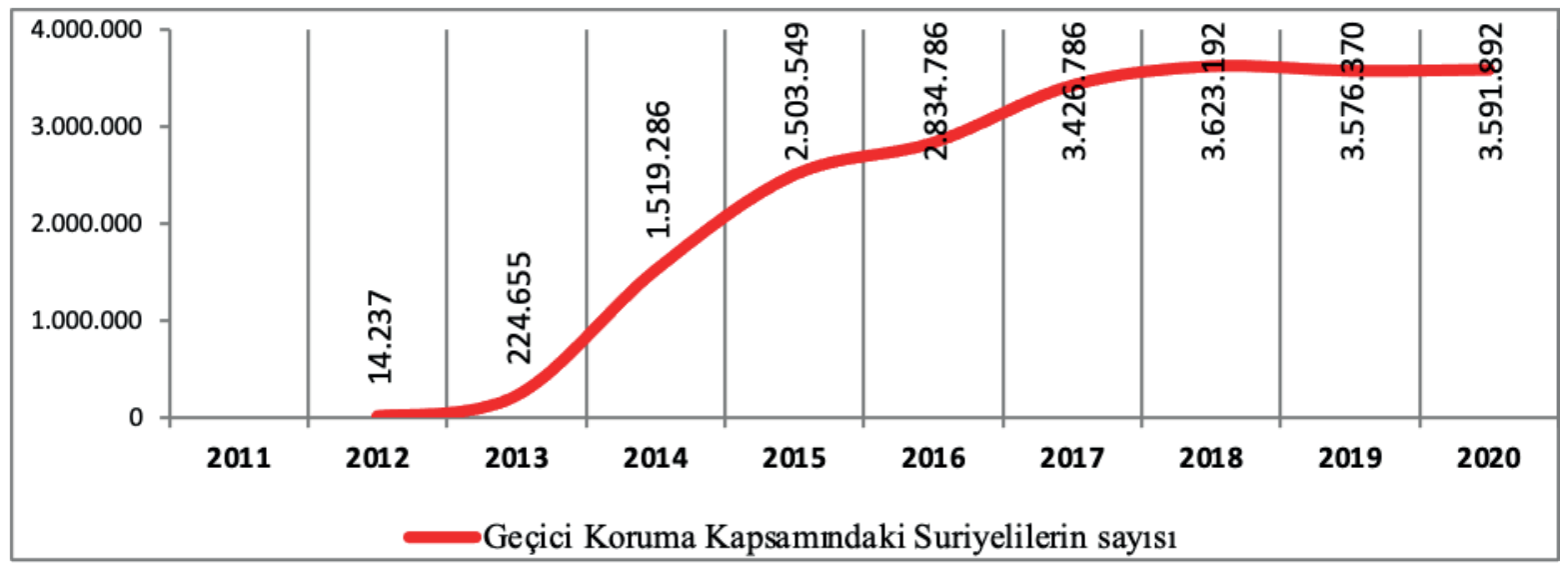

Şekil 1: Türkiye'deki Geçici Koruma Kapsamındaki Suriyelilerin² Dağılımı (2011-2020).

Figure 1: Distribution of Syrian Under Temporary Protection in Turkey (2011-2020).

\footnotetext{
1 Türkiye, 1951 tarihli Cenevre Sözleşmesi’ni “coğrafi çekince/kısıtlama” şartıyla kabul etmiştir. Bu kapsamda Türkiye’de bulunan Suriyeliler için 'Geçici Koruma Kapsamındaki Suriyeliler' tanımlaması kullanılmaktadır. Avrupa ülkelerinden gelenleri "mülteci” olarak kabul eden Türkiye, diğer sığınmacıları "şartlı mülteci” veya "ikincil koruma" statüsüyle tanımlamaktadır. Bu çalışmada, Türkiye'de bulunan Suriyeliler için Türkiye'deki yasal idari tanımlamadan bağımsız "Suriyeli Mülteciler" ifadesi kullanılmıștır.

2 Göç İdaresi Genel Müdürlü verileri açıllarken “Geçici Koruma Kapsamındaki Suriyeliler” tanımlaması kullanmaktadır. Ancak daha önce de vurgulandığı gibi bu çalışmada, Türkiye’de bulunan Suriyeliler için "Suriyeli Mülteciler” ifadesi kullanılmıştır.
} 
yaşanan göçlerin toplam sayısının 1244000 kişi civarında olduğu açıklanmaktadır (Akgündüz, 1998, s.112). Başka bir kaynakta ise Balkanlar'dan Türkiye'ye yönelik göçlerin yaklaşık 1445179 kişi olduğunu vurgulanmaktadır (McCarthy, 1999'dan aktaran: Çetin, 2008, s.57). Literatürde Balkan göçlerine ilişkin farklı sonuçlara rastlanılmaktadır. Ancak Balkan göçlerinin yakın dönemde Suriye'den gelen göçlerin yarısından daha az olduğunu görülmektedir.

Suriye kaynaklı göçlerden önce Türkiye, coğrafi konumu ve kültürel mirası nedeniyle farklı nicelik ve nitelikte göçlerin merkezi olmuştur. Osmanlı Devleti'nde XVIII. yüzyılda başlayan göçler; XIX. yüzyılda gittikçe hızlanmıştır. Bu göçler batıdan doğuya, Kafkaslar ve Rumeli'den Anadolu'ya doğru nüfus akışına neden olmuştur (Karpat, 2017, s.94). Osmanlı bakiyesi topraklardan kitlesel olarak Anadolu'ya gelen göçlerin bir kısmı zorunlu, bir kısmı gönüllü olarak gerçekleşmiştir. Cumhuriyet döneminde artarak devam eden bu göçler; 19231945 dönemi, 1945-1980 dönemi ve 1980 sonrası olmak üzere tarihsel olarak üç aşamada irdelenebilir (İçduygu ve Sirkeci, 1999, s.263-265).

Türkiye'de 1960'lı yıllarda ise kitlesel olarak dış göçler başlamıştır. Başta Almanya olmak üzere birçok Avrupa ülkesiyle imzalanan işgücü anlaşması yapılmıştır. Küreselleşmenin etkisiyle 1980 sonrasında Türkiye, farklı göçmen tipleriyle karşılaşmıştır. Göç veren ülkeler arasında bulunan Türkiye, yavaş yavaş göç alan ülkeler arasına anılmaya başlamıştır. 19802000 döneminde, çevre ülkelerde yaşanan savaş ve iç karışıklıklar nedeniyle Türkiye büyük göç dalgalarına maruz kalmıştır. Özellikle İran Devrimi, İran-Irak Savaşı, Afganistan'ın işgali, Körfez Savaşı, Amerika'nın Irak’1 işgali milyonlarca kişiyi yerinden yurdundan ederek mülteci durumuna düşürmüştür. 1988-2000 döneminde komşu ülkeler Irak ve Bulgaristan'dan göçler gelmiştir. Bosna Hersek ve Kosova'dan gelen göçlerle birlikte ülke nüfusuna yaklaşık 900000 kişi eklenmiştir (GİGM, 2016, s.23). Ayrıca 1990'da Sovyetler Birliği’nin dağılmasıyla bağımsızlı̆̆ını ilan eden ülkelerden Türkiye’ye yönelik göç dalgaları başlamıştır. Türkiye, bu süreçte aynı zamanda Afrika'dan Avrupa'ya bir geçiş güzergâhı olarak kullanılmaya başlamıştır. Yakın bir döneme kadar göç veren ülkelerden biri olarak bilinen Türkiye; göç alan bir ülke, aynı zamanda göçlerin transit geçiş güzergâhına dönüşmüştür.

2011 yllında Suriye'de çıkan iç savaş nedeniyle başlayan kitlesel göçler; Türkiye'nin temel sorunlarından biri olmuştur. Türkiye, savaşın başladığı günden bugüne coğrafi yakınlık, komşuluk ilişkileri, akrabalık bağları, inanç ve kültürel yakınlık, zulümden ve ölümden kaçan mazlum algısı gibi sebeplerle Suriye halkına "açık kapı politikası" uygulamıştır. 29 Nisan 2011 tarihinde Hatay iline bağlı Reyhanlı ilçesinde bulunan Cilvegözü sınır kapısında Suriye Arap Cumhuriyeti vatandaşı olan 252 kişinin ülkeye kabul edilmesiyle göçler başlamıştır (Erdoğan, 2015, s.5; Dinçer, Federici, Ferris, Karaca, Kirişçi ve Çarmıklı, 2013, s.7).

Göç İdaresi Genel Müdürlüğü 2011 yılında kaç kişinin Türkiye'ye girişyaptığına dairherhangibirveriaçılklamamaktadır. 2012 yılında 14237 kişi olan Türkiye'deki geçici koruma kapsamındaki Suriyelilerin sayısı 2014 yılında 1519286 kişiye ulaşmıştır. 2013-2014 döneminde Suriyelilerin sayısı altı kat artmıştır. 2018 yılında 3623192 kişiye ulaşan Türkiye'deki Suriyelilerin sayısı en yüksek noktaya ulaşmıştır. 2017 yılı itibariyle Türkiye'deki Suriyelilerin sayısındaki artış eğilimi düz bir grafik çizmemektedir (Şekil 1).

Göç İdaresi Genel Müdürlüğü’nce ortaya konulan verilere göre 2020 yılı haziran ayı verilerine göre 3591892 Suriyeli geçici koruma statüsü kapsamında Türkiye'de yaşamaktadır (Şekil 1). Göç İdaresi Genel Müdürlüğ̈̈’ne ait bu veriler uluslararası kuruluşlar tarafindan da teyit edilmektedir. United Nations High Commissioner for Refugees (UNHCR) verilerine göre 2011-2020 döneminde 5,6 milyondan fazla Suriyelinin ülkesini terk ederek Lübnan, Türkiye, Ürdün, Irak ve diğer bazı ülkelere göç ettiğini açıklamaktadır. Savaş nedeniyle farklı ülkelere göç eden Suriyeli mültecilerin \%64'ünün Türkiye'de sığındığı belirtilmektedir (UNHCR 2020).

Suriye'den gelen yeni göç dalgaları ve Türkiye'den kısmen de olsa Avrupa ülkelerine geçenler nedeniyle Türkiye'deki Suriyeli mülteci sayısı sürekli değişmektedir. 2020 y1lı 27 Şubat-15 Mayıs döneminde Türkiye'den Yunanistan'a geçen Suriyeli mültecilerin sayısının 153320 kişiyi aştığı açıklanmıştır (GIGMa,15.05.2020). Avrupa ülkelerine geçişler olsa da Türkiye'de bulunan Suriyelilerin sayısının giderek artmakta olduğu görülmektedir. Bu artışın temel nedeni Suriye'de yaşanan çatışmalardan etkilenen kişilerin sayının artmasından kaynaklanmaktadır. Ayrıca, Türkiye'de Göç İdaresi Genel Müdürlüğü bünyesinde yürütülen çalışmalar kapsamında, göç verileri daha kontrollü ve kapsamlı bir şekilde kayıt altına alınmaya başlamıştır. Sistemli bir şekilde tutulan göç kayıtlarının güncel ve gerçekçi sonuçlar sunduğu gözlenmektedir (GİGMb,11.03.2020).

Suriye'deki savaşın dokuzuncu yılına girdiği 2020 yılında Türkiye'deki Suriyelilerin sayısı atmaya devam etmektedir. 
Savaş ve çatışma uzadıkça Suriyelilerin "misafirlik" süreci de uzamaktadır. Bu durum Türkiye'de yerel halk için ve Suriyeli Mülteciler için birtakım sorunlara neden olmaktadır. Özellikle Suriyeli nüfusun yoğun yoğunlaştığı İstanbul, Gaziantep, Hatay, Şanlıurfa, Adana, Mersin, Bursa, İzmir, Konya, Kilis, Kahramanmaraş gibi şehirlerde yaşanan olaylar dikkat çekmektedir. Zaman zaman yaşanan sorunların bireysel alanı aşarak "toplumsal olaylara” dönüştüğü gözlenmektedir.

Literatürde Suriyeli mülteciler ile ilgili yapılan çalışmalara bakıldığında; amaç ve içerik olarak farklı konularda birçok çalışmanın yapıldığı görülmektedir. Özellikle son dönemde Türkiye'deki basın ve medyaya konu olan Suriyeli temasına ilişkin önemli araştırmalar yapılmıştır (Çakır, 2013; Ataman, 2014; Ongun, 2014; Pandır, Efe ve Paksoy, 2015; Göker ve Keskin, 2015; Ardıç ve Çobaner, 2015; Çağlar ve Özkır 2015; Özdemir ve Öner-Özkan 2016; Bayram, 2016; Doğanay ve Çoban Keneş, 2016; Güran ve Yiğitbaşı 2016; Çoban Keneş, 2016; Boztepe, 2017). Aynı şekilde Suriyelilerle ilgili güvenlik, asayiş ve uyum konusunu ele alan birçok çalışma bulunmaktadır (Dinçer vd., 2013; Orhan ve Gündoğar, 2015; Erdoğan, 2015; Ağır ve Sezik 2015; Canyurt, 2015; Tunç 2015; Karataş, 2015; Demir, 2015, Karademir ve Doğan, 2019). Söz konusu bu çalışmalarla birlikte Suriyeli mültecileri ele alan farklı konularda araştırmalar yapılmaktadır. Mesela (Ekici, 2019) Türkiye'de Suriyeli mültecilere yönelik tehdit algılarını alan yazındaki bulgular ışı̆̆ında incelemiştir. Bu çalışmada, 2014-2017 yılları arasındaki makaleleri ve raporları kapsamında, Türkiye'de yerel halkın, Suriyeli mültecilere yönelik tutumları irdelenmiş̧ir. Ancak, bugüne kadar yapılan çalışmalar arasında "toplumsal olaylara" odaklanan araştırmaların oldukça sınırlı kaldığ 1 söylenebilir. Oysa ev sahibi halk ile Suriyeli mülteciler arasında zaman zaman yaşanan toplumsal olaylar büyük tehlike arz etmektedir. Bazı asayiş olaylarının birdenbire nasıl kitlesel bir linç olayına dönüştüğü, basına yansıyan haberlerde görülmektedir. Söz konusu bu 'toplumsal olaylar' büyük sorunlara neden olabilir. Bu açıdan ev sahibi yerel halk ile Suriyeli mülteciler arasında yaşanan toplumsal olayları, mercek altına alıp inceleyen araştırmalara ihtiyaç duyulmaktadır.

\section{VERİ VE YÖNTEM}

$\mathrm{Bu}$ çalışmada Türkiye'de bulunan Suriyeli mülteciler ile ev sahibi halk arasında yaşanan toplumsal olayların dağılımının zaman ve mekân perspektifinde ortaya konulması amaçlanmıştır. Araştırmanın tematik çerçevesini oluşturan "toplumsal olay" kavramı: iki ya da daha çok kişinin aynı amaçla bir araya gelerek gerçekleştirilen toplu aktiviteler (McAdam ve Snow, 1997, s.24) şeklinde tanımlanmaktadır. Bu çalışmada kullanılan toplumsal olay kavramı; Türkiye'de bulunan Suriyeli mültecilerin sosyal yaşamda neden olduğu değişimler nedeniyle; gerilim hisseden bazı grupların hedeflerine erişmek amacıyla bir araya gelerek yaptıkları eylemleri tanımlamaktadır. Bu eylemler, toplumdaki sosyokültürel, politik ve ekonomik değişime karş1 ortaya konulan kolektif tepkilerdir (Can ve Taşç1, 2016, s.151). Yürüyüşler, sembolik gösteriler, lobi faaliyetleri ve kamuoyu oluşturma çabaları, seremoniler ve bildiri dağıtımı, protesto eylemleri gibi bir grup tarafindan yapılan birçok eylem "toplumsal olay" kapsamına girmektedir. Türkiye'de bulunan Suriyeli mültecilere yönelik zaman zaman bu tür olayların yaşandığı gözlenmektedir.

Çalışmanın doğası gereği, nitel araştırma yöntemlerinden doküman analizi tekniği kullanılmıştır Doküman analizi; araştırılması amaçlanan konu kapsamında her türlü olgu ve olayla ilgili bilgi içeren yazılı belge ve materyallerin taranarak analiz edilme sürecindir (Yıldırım ve Şimşek, 2013, s.259). Herhangi bir kaynak, kitap veya belgenin bazı özelliklerinin sayısallaştırılıp belirlenmesinde doküman incelemesi yapılabilmektedir. Doküman incelemesi tekniği, araştırma konusuyla ilgili kitap, makale, gazete, rapor, proje, afişler, iş ilanları, duvar yazıları vb. yazılı materyallerde verilmek istenen mesajları sayısallaştırarak aktarılmasına olanak sağlamaktadır. $\mathrm{Bu}$ teknikle, araştırma konusuyla ilgili veriler incelenerek belli başlıklar altında kodlanıp sınıflandırılır. Bu kod ve sınıflandırma esası araştırmayla ilgili bulgularının sistemli bir şekilde sunulmasını sağlar (Merriam, 1998, s.58).

Çalışmanın temel veri kaynağını, basında yer alan Suriyeli mülteciler ile ilgili haberler oluşturmaktadır. Araştırmada verilerin derlenmesi ve analizi için araştırmacılar tarafından hazırlanan "Haber Sinıflandırma ve Kodlama Formu" oluşturulmuştur. 6 farklı başlık şeklinde kategorileştirilen bu formda; "Haberin başlığı, Haberin yeri, Haberin tarihi, Haberin konusu, haberin alındığı kaynak adresi ve haberin erişim tarihi" başlıklarına yer verilmiştir (Tablo 1).

Daha önce de vurgulandığı üzere araştırmanın temel amacı Türkiye'de kaç farklı yerde kaç defa toplumsal olay yaşandığının belirlenmesidir. Dolayısıyla çalışmada gazetelerin olayı ele alış biçimi, sunuş anlayışı değil; esas olan olayların yeri ve sayısının tespit edilip ortaya konulmasıdır. Araştırma konusu hassas bir konu olması nedeniyle söz konusu haberin kaynağını ve doğruluğunun farklı kaynaklardan teyit edilmesi gereklidir. Haberin kaynağının teyit edilmesi için her haberin en az 2 farklı 
Tablo 1: Haber Sınıflandırma ve Kodlama Formu.

Tablo 1: News Classification and Coding Form.

\begin{tabular}{|c|c|c|c|c|c|}
\hline $\begin{array}{l}\text { Haberin } \\
\text { başlığı }\end{array}$ & $\begin{array}{l}\text { Haberin } \\
\text { yeri }\end{array}$ & $\begin{array}{l}\text { Haberin } \\
\text { Tarihi }\end{array}$ & Haberin konusu ${ }^{3}$ & $\begin{array}{l}\text { Haberin alındığı kaynak } \\
\text { adresi }\end{array}$ & Erişim Tarihi \\
\hline $\begin{array}{l}\text { İmir Torbalı'da } \\
\text { tehlikeli gerginlik! }\end{array}$ & İzmir-Torbalı & 08.04 .2017 & $\begin{array}{l}\text { İzmir'in Torbalı ilçesinde, bir çocuğu dövdüğü öne sürülen } \\
\text { Suriyeli gruba, mahalle sakinleri sopa ve tırpanlarla saldırdı. } \\
\text { 1'i ağır } 30 \text { kişinin yaralandığı olay sonrası kentteki yaklaşık } \\
500 \text { kişilik Suriyeli grup mahalleyi terk etti. }\end{array}$ & $\begin{array}{l}\text { https://www.haber- } \\
\text { turk.com/gundem/ } \\
\text { haber/1454871-torbali- } \\
\text { daki-kavga-sonrasi-suriye- } \\
\text { liler-ayrildi }\end{array}$ & 05.04 .2020 \\
\hline $\begin{array}{l}\text { İkitelli'de tehlikeli } \\
\text { gerginlik; } \\
\text { Suriyelilere linç } \\
\text { girişimi }\end{array}$ & $\begin{array}{l}\text { İstanbul / } \\
\text { Küçükçekmece }\end{array}$ & 25.08 .2014 & $\begin{array}{l}\text { Küçükçekmece'nin İkitelli semtinde Suriyeli } 2 \text { kişinin bir Türk } \\
\text { çocuğunu dövdüğü iddiasıyla toplanan mahalle sakinleri, } \\
\text { Suriyelilere ait ev iş yerlerine saldırdı... }\end{array}$ & $\begin{array}{l}\text { https://www.posta.com. } \\
\text { tr/ikitellide-tehlikeli-ger- } \\
\text { ginlik-suriyelilere-lin- } \\
\text { c-girisimi-haber-fotog- } \\
\text { raf-242122-2 }\end{array}$ & 04.04 .2020 \\
\hline
\end{tabular}

gazetede yer alması esas alınmıştır. Konuyla ilgili en az 2 farklı gazetede yer alan haberler, araştırmanın verilerine dâhil edilmiştir.

Hazırlanan kılavuz form kapsamında, farklı gazetelerin internet sitelerinde bulunan arama butonları üzerinde; "Suriyeli, mülteci, sığınmacı, gerginlik, tehlike, mahalleli, Suriyeli gerginliği, tehlikeli gerginlik" anahtar kelimeleri kullanılarak sitelerindeki çevrimiçi haberler taranmıştır. 01.03.2011 ile 30.06.2020 tarihleri arasındaki haberler filtrelenerek gazetelerin internet sitelerindeki "toplumsal olay" konulu haberler tespit edilerek; formdaki her bir başlığa uygun olacak şekilde taranıp kodlanarak arşivlenmiştir. 2011-2020 yılları arasında yaşanan ancak "toplumsal olay" içeriğine sahip olmayan haberler elenmiştir.

Çalışmanın bağımlı değişkenini oluşturan "Suriyeli mültecilere yönelik toplumsal olayların sayısı" ile ilgili veriler, farklı gazetelerin internet sitelerinde yer alan haberlerin taranmasıyla ortaya çıkarılmıştır. $\mathrm{Bu}$ nedenle araştırma kapsamında ortaya konulan tespitlerin güvenilirliği ve geçerliliği, bahse konu haberlerin güvenilirliğine ve geçerliliğine bağlıdır. Ayrıca basında Suriyeli mülteciler ile ev sahibi halk arasında yaşanan toplumsal olayların hangi meselelerden dolayı ortaya çıktığı ve nasıl sonuçlandığını açıklayan örnek haberlere de yer verilmiştir. Böylece çalışmanın kapsamı içerik olarak desteklenerek zenginleştirilmiştir. Araştırmada geçmişe yönelik bir durum tespiti yapılarak ve bu soruna yönelik çözüm önerileri sunulmuştur. Çalışma, Türkiye'de bulunan Suriyeli mülteciler ile ev sahibi halk arasında; 2011-2020 döneminde yaşanan toplumsal olayların sayısını ve coğrafi dağılımını ortaya koyan ilk araştırmalardan biri olması nedeniyle literatüre katkı sağlayacağı düşünülmektedir.

\section{BULGULAR}

\subsection{Suriyelilerin Türkiye Genelinde Dağılımı}

Yaşanan savaş nedeniyle zorunlu olarak ülkelerini terk eden Suriyeli mültecilerin en çok giriş yaptığı ve ikamet ettiği ülke Türkiye'dir. Daha önce de vurgulandığı gibi 2020 yılı haziran ayı verilerine göre 3591892 Suriyeli mülteci, Geçici Koruma Statüsü kapsamında Türkiye'de barınmaktadır. Türkiye'de bulunan Suriyeli mültecilerin \%2'si Adana, Osmaniye, Kahramanmaraş, Hatay ve Kilis illerinde bulunan 7 adet geçici barınma merkezinde kalmaktadır (Tablo 2). Suriyeli mültecilerin \%98'i ise kendi imkânlarıyla ülkenin 81 ilinde halkın arasında

Tablo 2: Geçici Barınma Merkezinde (GBM) Bulunan Suriyeli Mültecilerin Dağılımı.

Table 2: Distribution of Syrian Refugees in Temporary Accommodation Center.

\begin{tabular}{lllll}
\hline iı & GBM Sayısı & GBM Sayısı & GBM Mevcudu & Toplam \\
\hline Adana & 1 & Sarıçam & 21085 & $\mathbf{2 1 0 8 5}$ \\
Kilis & 1 & Elbeyli & 8558 & $\mathbf{8 5 5 5}$ \\
Kahramanmaraş & 1 & Dulkadiroğlu & 10826 & $\mathbf{1 0 8 2 6}$ \\
& & Altınözü & 2669 & $\mathbf{1 0 4 8 0}$ \\
Hatay & 3 & Yayladağı & 3890 & 3921 \\
& & Apaydın & 11704 & $\mathbf{1 1 7 0 4}$ \\
Osmaniye & 1 & Cevdetiye & & $\mathbf{6 2 6 5 3}$ \\
Geçici Barınma Merkezinde bulunan Suriyelilerin toplam sayısı & & $\mathbf{3 5 2 9 2 3 9}$ \\
Geçici Barınma Merkezi dişında bulunan Suriyeli sayısı & & $\mathbf{3 5 9 1 8 9 2}$ \\
Türkiye'deki bulunan toplam Suriyeli Sayısı & & & \\
\hline
\end{tabular}

Kaynak: Göç Idaresi Genel Müdürlüğü 25.06.2020 tarihi verileri.

3 Haberin konusu: Haber kaynağının olayı aktarış biçimine hiçbir şekilde müdahale edilmeden, toplumsal olayın sunulduğu haber metninin ilk paragrafını oluşturmaktadır. 
yaşamaktadır (Şekil 4). 2011 yılında kargaşanın başladığı süreçte Türkiye'ye sığınan ilk gruplar, geçici kabul merkezleri, çadırkentler, konteyner kentler ve barınma merkezlerine yönlendirmiştir. Göçlerin kitleler halinde artarak devam etmesi nedeniyle Suriyeli mültecilere ülke içerisinde istedikleri illere yerleşme izni vermiştir (Erdoğan, 2019, s.7).

Suriyeli mültecilerin Türkiye genelinde dağılımına bakıldığında belirli illerdeki yoğunluk dikkat çekmektedir (Şekil 4). Sayısal bakımdan Suriyeli mültecilerin en fazla yerleştikleri ilk 10 şehir; İstanbul, Gaziantep, Hatay, Şanlıurfa, Adana, Mersin, Bursa, İzmir, Konya ve Kilis şeklinde sıralanmaktadır
(Tablo 3). Göç İdaresi Genel Müdürlüğü hangi ilde kaç Suriyeli sığınmacının yaşadığını kayıt altına alarak web sitesinde bu sayıları sürekli güncelleyip yayımlamaktadır. Türkiye'de kayıtlı bulunduğu illerde yaşamayan Suriyeli mültecilerin olduğu bilinmektedir. Ancak Suriyeli mülteciler sağlık, eğitim, ekonomik yardım imkânlarına kayıtlı olduğu ilde daha kolay şekilde ulaştığı bilinmektedir. Bu nedenle kayıtlı olduğu ilin dışına çıkan Suriyeli mültecilerin oranının oldukça düşük olduğu söylenebilir.

Suriyeli mültecilerin Türk vatandaşlarına oranına bakıldığında; şu anda Suriyeli mültecilerin Türkiye nüfusuna

Tablo 3: Türkiye'deki Suriyeli Mültecilerin İllere Göre Dağılımı.

Table 3: Breakdown of Syrian Refugees in Provinces in Turkey.

\begin{tabular}{|c|c|c|c|c|c|c|c|}
\hline iller & $\begin{array}{l}\text { Suriyeli } \\
\text { mülteci nüfus }\end{array}$ & il Nüfusu & $\begin{array}{l}\text { Suriyeli mülteci nüfusun } \\
\text { il nüfusuna oranı (\%) }\end{array}$ & iller & $\begin{array}{l}\text { Suriyeli } \\
\text { mülteci nüfus }\end{array}$ & İ Nüfusu & $\begin{array}{l}\text { Suriyeli mülteci nüfusun } \\
\text { il nüfusuna oranı (\%) }\end{array}$ \\
\hline İstanbul & 501462 & 15519267 & 3,23 & Aksaray & 3663 & 416367 & 0,88 \\
\hline Gaziantep & 448980 & 2069364 & 21,70 & Sivas & 3546 & 638956 & 0,55 \\
\hline Hatay & 433162 & 1628894 & 26,59 & Trabzon & 3444 & 808974 & 0,43 \\
\hline Şanlıurfa & 420621 & 2073614 & 20,28 & Bolu & 3221 & 316126 & 1,02 \\
\hline Adana & 247421 & 2237940 & 11,06 & Kastamonu & 3189 & 379405 & 0,84 \\
\hline Mersin & 213353 & 1840425 & 11,59 & Çorum & 2898 & 530864 & 0,55 \\
\hline Bursa & 176358 & 3056120 & 5,77 & Uşak & 2509 & 370509 & 0,68 \\
\hline İzmir & 146244 & 4367251 & 3,35 & Antalya & 2354 & 2511700 & 0,09 \\
\hline Konya & 115097 & 2232374 & 5,16 & Van & 2266 & 1136757 & 0,20 \\
\hline Kilis & 108189 & 142490 & 75,93 & Kütahya & 1971 & 579257 & 0,34 \\
\hline Ankara & 96989 & 5639076 & 1,72 & Kırıkkale & 1796 & 283017 & 0,63 \\
\hline Kahramanmaraş & 93050 & 1154102 & 8,06 & Düzce & 1771 & 392166 & 0,45 \\
\hline Mardin & 88629 & 838778 & 10,57 & Muş & 1538 & 408809 & 0,38 \\
\hline Kayseri & 76982 & 1407409 & 5,47 & Kırşehir & 1447 & 242938 & 0,60 \\
\hline Kocaeli & 55340 & 1953035 & 2,83 & Bitlis & 1198 & 348115 & 0,34 \\
\hline Osmaniye & 48920 & 538759 & 9,08 & Ağrı & 1143 & 536199 & 0,21 \\
\hline Malatya & 29310 & 800165 & 3,66 & Erzurum & 1121 & 762062 & 0,15 \\
\hline Diyarbakır & 23117 & 1756353 & 1,32 & Karabük & 1074 & 248458 & 0,43 \\
\hline Adıyaman & 21883 & 626465 & 3,49 & Rize & 1065 & 343212 & 0,31 \\
\hline Sakarya & 15318 & 1029650 & 1,49 & Edirne & 1061 & 413903 & 0,26 \\
\hline Batman & 15285 & 608659 & 2,51 & Bingöl & 1055 & 279812 & 0,38 \\
\hline Şırnak & 14980 & 529615 & 2,83 & Tokat & 1048 & 612747 & 0,17 \\
\hline Manisa & 13473 & 1440611 & 0,94 & Kırklareli & 1017 & 361836 & 0,28 \\
\hline Tekirdağ & 12611 & 1055412 & 1,19 & Ordu & 905 & 754198 & 0,12 \\
\hline Denizli & 12126 & 1037208 & 1,17 & Amasya & 874 & 337800 & 0,26 \\
\hline Elazığ & 11889 & 591098 & 2,01 & Karaman & 823 & 253279 & 0,32 \\
\hline Muğla & 11290 & 983142 & 1,15 & Çankırı & 743 & 195789 & 0,38 \\
\hline Nevşehir & 10567 & 303010 & 3,49 & Zonguldak & 634 & 596053 & 0,11 \\
\hline Afyonkarahisar & 10224 & 729483 & 1,40 & Bilecik & 622 & 219427 & 0,28 \\
\hline Aydın & 7897 & 1110972 & 0,71 & Bartın & 317 & 198249 & 0,16 \\
\hline Burdur & 7891 & 270796 & 2,91 & Sinop & 197 & 218243 & 0,09 \\
\hline Samsun & 6792 & 1348542 & 0,50 & Giresun & 193 & 448400 & 0,04 \\
\hline Isparta & 5865 & 444914 & 1,32 & Kars & 177 & 285410 & 0,06 \\
\hline Çanakkale & 5515 & 542157 & 1,02 & Ardahan & 121 & 97319 & 0,12 \\
\hline Eskişehir & 5405 & 887475 & 0,61 & Erzincan & 113 & 234747 & 0,05 \\
\hline Niğde & 5247 & 362861 & 1,45 & Gümüşhane & 89 & 164521 & 0,05 \\
\hline Hakkari & 5179 & 280991 & 1,84 & Iğdır & 89 & 199442 & 0,04 \\
\hline Yozgat & 4906 & 421200 & 1,16 & Artvin & 38 & 170875 & 0,02 \\
\hline Balıkesir & 4755 & 1228620 & 0,39 & Tunceli & 37 & 84660 & 0,04 \\
\hline Siirt & 4290 & 330280 & 1,30 & Bayburt & 24 & 84843 & 0,03 \\
\hline Yalova & 3889 & 270976 & 1,44 & TOPLAM & 3591892 & 83154997 & 4,32 \\
\hline
\end{tabular}

Kaynak: Göç İdaresi Genel Müdürlüğü 25.06.2020 tarihi verileri 
oranı \%4,3'tür. Ancak bazı illerde Suriyeli mülteci nüfusun oranı, Türkiye vatandaşı olan ev sahibi nüfusu aşması dikkat çekmektedir. Mesela 142490 nüfusa sahip olan Kilis'te 108189 Suriyeli sığınmacı bulunmaktadır. İlde yaşayan toplam nüfus 250679'a yükselmiş̧ir (Şekil 5).

Suriyeli sığınmacı nüfusun il nüfusuna oranının yüksekliği bakımından ilk sırada yer alan Kilis’te, Suriyeli sığınmacı nüfusun ev sahibi yerel nüfusa oranı $\% 75,9$ 'ü bulmaktadır. Bazı illerde Suriyeli mültecilerin il nüfusuna oranı \%20'yi aşmaktadır. Mesela Hatay'da bulunan Suriyeli mültecilerin il nüfusuna oranı $\% 26,5$, Gaziantep \%21,7, Şanlıurfa \%20,2‘dir. Oransal bakımdan Suriyeli mülteciler, Mersin nüfusunun $\% 11,5$ 'u, Adana nüfusunun $\% 11$ 'i, Mardin nüfusunun $\% 10,5$ 'sine karşıllk gelmektedir. Söz konu bu üç ilde Suriyeli mültecilerin toplam nüfusa oranı $\% 10$ 'u aşmaktadır. Osmaniye nüfusunun $\% 9,1$ 'i Kahramanmaraş nüfusunun ise $\% 8,1$ 's1 Suriyelilerden oluşmaktadır. Bursa, Kayseri ve Konya illerinde Suriyeli mülteciler il nüfusunun $\% 5$ 'ine tekabül etmektedir. Malatya, Adıyaman, Nevşehir, İzmir ve İstanbul illerinde, Suriyeli mülteciler il nüfusunun \%3'üne karş1lık gelmektedir. 44 ilde Suriyeli mültecilerin il nüfusa oranı $\% 1$ 'in altında kalmaktadır. Suriyeli mültecilerin oranın en düşük olduğu iller ise Sinop, Giresun, Kars, Ardahan, Erzincan, Gümüşhane, Iğdır, Artvin, Tunceli ve Bayburt olarak sıralanmaktadır (Tablo 3).

Türkiye'de en fazla Suriyeli Mülteci, 501462 kişiyle İstanbul'da barınmaktadır. Suriyeli mültecilerin İstanbul nüfusuna oranı \%3,23'ü bulmaktadır. Ancak İstanbul'daki Suriyeli mülteciler, oransal olarak Türkiye ortalaması olan \%4,32'nin altında kalmaktadır (Şekil 2). Bu sonuç bir şehirdeki göçmen nüfusun oranı bakımından makul bir durum olduğu söylenebilir. 15519267 nüfusa sahip olan İstanbul'da Suriyeliler kalabalığın içerisinde pek fark edilmemektedir. Dolayısıyla il nüfusuna karşıllık çok yüksek oranda Suriyeliyi barındıran illerde; Suriyeli mültecilerden kaynaklı etkiler daha fazla hissedilmektedir. Suriyeli mültecilerin bazı şehirlerin demografik yapıyı önemli ölçüde değiştirmiştir. Bu değişim birtakım toplumsal olaylara yol açmaktadır. Bugüne kadar Türkiye'de konusu Suriyeli mülteciler olan kaç toplumsal olay yaşanmıştır? Yaşanan olaylar hangi illerde yoğunlaşmıştır? Söz konusu olayların sebepleri nelerdir ve bu olaylar nasıl sonuçlanmıştır? Konuyla ilgili cevaplanması gereken önemli sorulardır?

Toplumsal yaşamda, suç olarak tanımlanan hadiselerin yaşanması kaçınılmazdır. Suçların niteliği ve niceliği toplumun sosyokültürel yapısına göre değişmektedir. Ancak olayın öznesi olan tarafların kimliği, sonuçları etkilemektedir. Son dönemlerde Türkiye'de yazılı ve görsel medyada bazı haberlere konu olan Suriyeli mültecilerin durumu bu olayların açık örneklerini oluşturmaktadır. Ev sahibi halk arasında zaman zaman yaşanan bazı asayiş olaylarının taraflarından biri şayet Suriyeli ise söz konusu olayla ilgili haber, kısa sürede çevreye yayılmakta ve adeta kitlesel bir linç olayına dönüşme ihtimali ortaya çıkmaktadır.

\subsection{Suriyeli Mültecilere Yönelik Toplumsal Olayların} Türkiye Genelinde Dağılımı

Toplumsal olaylar (protesto dalgaları / waves of protest); siyasi ve iktisadi krizler, teknolojik değişimin toplumsal yaşamdaki etkileri, demografik değişimler ve göçler nedeniyle toplumda yaşanan sosyal sorunlar neticesinde ortaya çıkmaktadır (Tarow, 1994'dan aktaran Can ve taşç1, 2016, s.153). Bir başka ifadeyle "toplumsal olay" toplumun genelini ilgilendiren ve etkileyen bir sonuç doğurmaktadır. Toplumdaki ani değişikliklerin

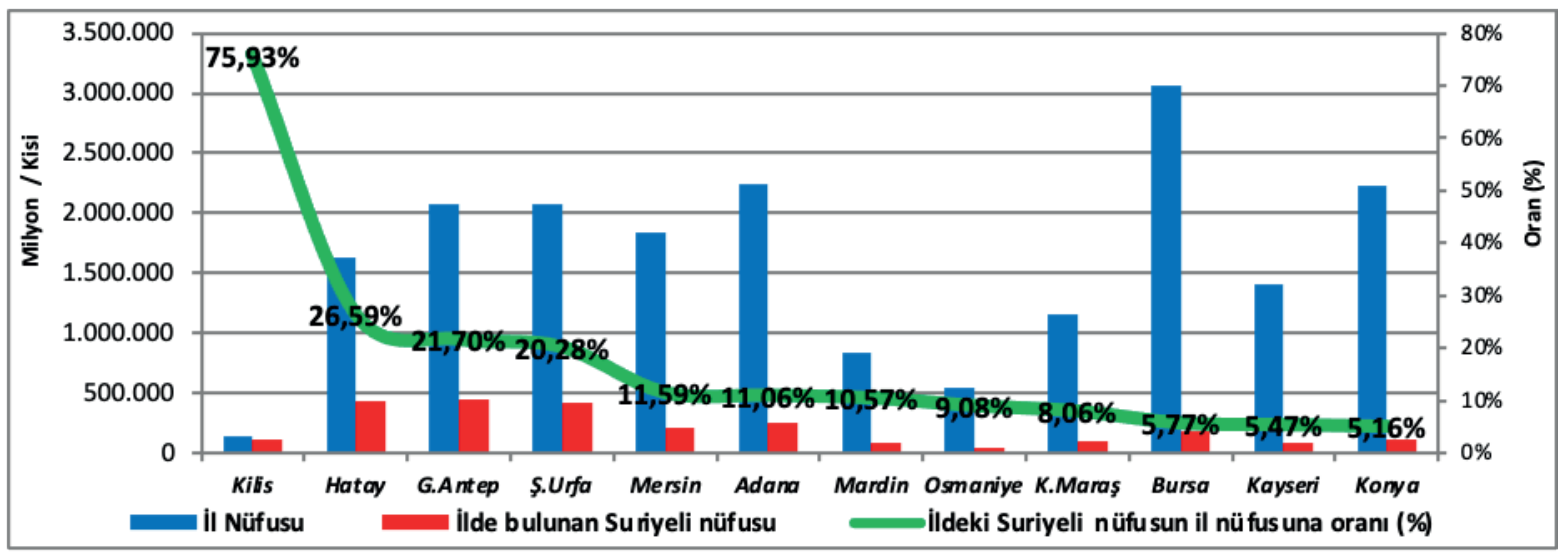

Şekil 2: Suriyeli Mültecilerin Ev Sahibi III Nüfusuna Oranı \%5'ten Yüksek Olan 12 İl.

Figure 2: 12 Provinces with more than 5\% Higher Ratio of Syrian Refugees in Comparison to Total Host Provinces. 
ortaya çıardığı sosyal düzensizlik ortamı, toplumsal olaylara ortam hazırlar. Sosyal yaşamda görülen ani değişimler toplumsal gerilim ve bazı konularda göreceli mahrumiyet duygularına sebep olmaktadır. Sosyal kontrol mekanizmasını zayıflatan bu durum kolektif davranışın ortaya çıkmasına yol açar (Lang ve Lang, 1961; Tarrow, 1994). Toplumsal olaylar; ekonomik, politik ve sosyal gelişmelere yönelik tepkilerle ortaya çıkmıştır. Ancak postmodern toplumlarda daha çok yaşam biçimi ve düzeyine karş1 bir tehdit unsuru olarak durumlara karşı ortaya çıkan tepkiler, toplumsal olaylara dönüşmektedir (Buechler, 1995). Toplamsal olaylar, günümüzde daha çok günlük sosyal hayatı tehdit eden baskılara odaklanmaktadır. Toplumsal olay niteliği taşıyan sembolik eylem ve araçların asıl amacı baskıların bertaraf edilmesidir (Bernstein, 2005, s. 54).

Suriyeli mültecileri konu alan araştırmalar, Türkiye'de Suriyelilerin toplumda genel olarak kabul görüldüğü vurgulanmaktadır. Ancak yaşanan toplumsal olaylar, bazı konularda toplumun tereddütleri olduğu gözlenmektedir (Tunç, 2015, s.58). Halk arasında eğitim, sağlık, belediye gibi kamu hizmetlerinin yetersizliğinin Suriyeli mültecilerden kaynaklandığı algısı oluşabilmektedir. Aynı şekilde Suriyeliler, işsizlik, düşük gelir, kira artışı gibi ekonomik kaygıların kaynağı olarak görülebilmektedir. Çalışma ve oturma izni, vatandaşlık gibi temel haklar noktasında birtakım endişeler gündeme gelmektedir. Bu açıdan toplumsal olayların nerede yaşandığı ve olaylara neden olan faktörlerin tespit edilmesi sorunların çözümü için oldukça önemlidir.

Araştırmanın yöntem kısmında ayrıntılı şekilde izah edildiği gibi farklı gazetelerin internet sitelerindeki çevrimiçi haberler; "Suriyeli, mülteci, sığınmacı, gerginlik, tehlike, mahalleli" anahtar kelimeler esas alınarak taranmıştır. Sonuç olarak Mart 2011-Temmuz 2020 sürecinde Türkiye'de 37 ilde Suriyeli mülteciler ile ev sahibi Türkiye vatandaşları arasında toplam 186 toplumsal olay yaşandığı tespit edilmiştir (Şekil 3). Söz konusu bu olayların 147 tanesi 14 ilde meydana gelmiştir. Söz konusu bu iller Şanlıurfa, İstanbul, Gaziantep, Ankara, İzmir, Adana, Hatay, Konya, Mersin, Bursa, Kilis, Mardin, Sakarya ve Kahramanmaraş şeklinde sıralanmaktadır (Şekil 6).

Tablo 4: Türkiye'de Suriyeli Mülteciler ile Ev Sahibi Halk Arasında Meydana Gelen “Toplumsal Olay” Sayısının Yıllara Göre Dağılımı (2011-2020). Table 4: Breakdown of Number of Years of Social Incidents in Turkey (2011-2020) between Syrian Refugees and Host People.

\begin{tabular}{llll}
\hline Yıl & Türkiye'deki Suriyeli Mülteci Sayısı & Toplumsal Olay Sayısı & Toplam Olayların Yıl Bazında Oransal Dağılımı \% \\
\hline $\mathbf{2 0 1 1}$ & - & - & - \\
$\mathbf{2 0 1 2}$ & 14237 & 5 & 3 \\
$\mathbf{2 0 1 3}$ & 224655 & 3 & 2 \\
$\mathbf{2 0 1 4}$ & 1519286 & 37 & 19 \\
$\mathbf{2 0 1 5}$ & 2503549 & 21 & 11 \\
$\mathbf{2 0 1 6}$ & 2834786 & 20 & 11 \\
$\mathbf{2 0 1 7}$ & 3426786 & 44 & 24 \\
$\mathbf{2 0 1 8}$ & 3623192 & 28 & 15 \\
$\mathbf{2 0 1 9}$ & 3576370 & 23 & 12 \\
$\mathbf{2 0 2 0}$ & 3591892 & 5 & 3 \\
$\mathbf{2 0 1 1 - 2 0 2 0}$ dönemindeki yaşanan Toplam Olay Sayısı & $\mathbf{1 8 6}$ & $\mathbf{1 0 0}$ \\
\hline
\end{tabular}

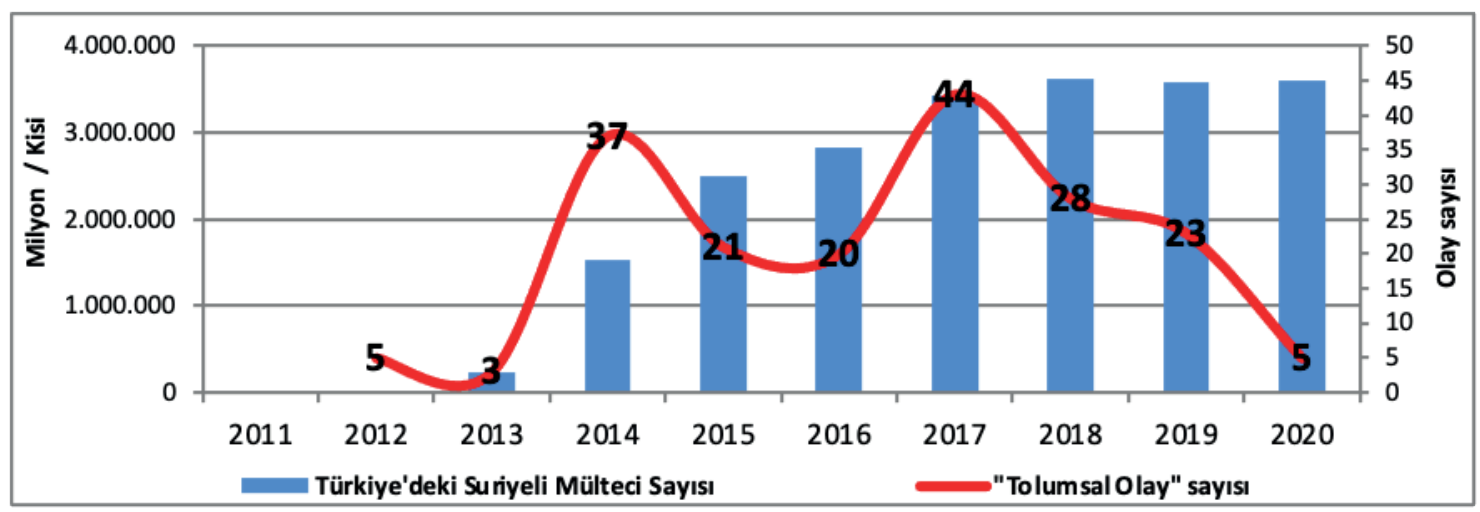

Şekil 3: Türkiye'de Suriyeli Mülteciler ile Ev Sahibi Halk Arasında Meydana Gelen “Toplumsal Olay” Sayısının Yıllara Göre Dağılımı (2011-2020).

Figure 3: Breakdown of Number of Years of Social Incidents in Turkey (2011-2020) between Syrian Refugees and Host People. 
Toplumsal olayların yıl bazında dağılımın bakıldığında, Savaşın başladığı 2011 yılında Türkiye'de basına yansıyan herhangi bir toplumsal olay görülmemektedir. 2012 yılında toplam 5 olay yaşanırken; 2013 yılında sadece 3 toplumsal olay yaşanmıştır. 2014 yılında 37 toplumsal olay meydana gelmiştir. 2013 yılında Türkiye'de bulunan Suriyeli sığınmacı sayısı 224655 iken 2014 yılında ise 1519286'ya yükselmiştir. Suriyeli mülteci sayısı 7 kat artarken bu süreçte yaşanan toplumsal olay sayısı 12 kat artmıştır (Şekil 4).

Türkiye'de bulunan Suriyelilerin sayısının 2503549 kişiye ulaştığı 2015 yılında, 3 toplumsal olay gerçekleşmiştir. Bir önceki döneme göre Suriyelilerin sayısı artmıştır; ancak yaşanan toplumsal olay sayısı düşmüştür. 2016 yılında Türkiye'de bulunan Suriyelilerin sayısı 2834786'ya yükselmesine rağmen bu dönemde yaşanan toplumsal olay sayısı azalmıştır. Ancak olay sayısının bir önceki döneme göre pek değişmediği aynı düzeyde kaldığı görülmektedir. Türkiye'de bulunan Suriyelilerin sayısının 3426786 kişiye ulaştığı 2017'de, konusu Suriyeli mülteciler olan toplam 44 toplumsal olay yaşanmıştır. Bu sayı aynı zamanda Türkiye'de 2011-2020 döneminde yaşanan toplumsal olay sayısının zirvesini oluşturmaktadır (Şekil 3).

Konusu Suriyeli mülteciler olan toplumsal olayların sayıs1, 2016 yılına kıyasla 2017 yılında yaklaşık üçe katlanmıştır. Suriyeli mültecilere yönelik veya konusu Suriyelilerle bağlantılı toplumsal gerginlik olaylarının sayısı International Crisis Group (ICG)’un hazırlamış olduğu, “Türkiye'deki Suriyeli mülteciler: Kentsel Gerilimleri Azaltmak” (2018) adlı raporda; 2017 yılında yaşanan toplumsam olaylarda; 24'ü Suriyeli mülteci, 11'i yerli

Tablo 5: Türkiye'de Suriyeli Mülteciler ile Ev Sahibi Halk Arasında Meydana Gelen Toplumsal Olayların III Bazında Dağılımı (2011-2020). Table 5: Distribution of Social Incidents by Province Occurring Between Syrian Refugees and Host People in Turkey (2011-2020).

\begin{tabular}{|c|c|c|c|c|c|c|c|c|c|c|c|}
\hline İller & 2011 & 2012 & 2013 & 2014 & 2015 & 2016 & 2017 & 2018 & 2019 & 2020 & İL TOPLAMI \\
\hline Şanlıurfa & - & - & 2 & 2 & 6 & 2 & 6 & 5 & 1 & 1 & 25 \\
\hline İstanbul & - & - & - & 2 & 3 & - & 4 & 1 & 8 & 1 & 19 \\
\hline Gaziantep & - & 1 & - & 7 & - & 4 & 2 & 3 & - & - & 17 \\
\hline Ankara & - & - & - & 3 & - & 2 & 3 & - & - & 1 & 9 \\
\hline İzmir & - & - & - & 2 & 1 & 2 & 2 & 2 & - & - & 9 \\
\hline Adana & - & - & - & 1 & - & 2 & 4 & 2 & - & - & 9 \\
\hline Hatay & - & 1 & 1 & 4 & 1 & - & - & - & 1 & - & 8 \\
\hline Konya & - & - & - & 1 & 1 & 2 & 4 & - & - & - & 8 \\
\hline Mersin & - & - & - & - & 1 & 2 & 2 & 1 & 2 & - & 8 \\
\hline Bursa & - & - & - & - & - & 1 & - & 5 & 2 & - & 8 \\
\hline Kilis & - & 2 & - & 3 & 1 & - & - & 1 & - & - & 7 \\
\hline Mardin & - & - & - & 3 & 1 & - & - & 1 & 2 & - & 7 \\
\hline Sakarya & - & - & - & - & - & - & 6 & 1 & - & - & 7 \\
\hline Kahramanmaraş & - & 1 & - & 3 & - & - & - & - & - & 2 & 6 \\
\hline Kayseri & - & - & - & 3 & 1 & - & 1 & - & - & - & 5 \\
\hline Denizli & - & - & - & - & - & - & 2 & 1 & 1 & - & 4 \\
\hline Kocaeli & - & - & - & - & - & - & - & 1 & 2 & - & 3 \\
\hline Aydın- & - & - & - & - & - & - & - & - & 2 & - & 2 \\
\hline Afyon & - & - & - & - & 1 & - & 1 & - & - & - & 2 \\
\hline Elazığ & - & - & - & - & - & - & - & 2 & - & - & 2 \\
\hline Antalya & - & - & - & - & - & - & 2 & - & - & - & 2 \\
\hline Edirne & - & - & - & - & 1 & 1 & - & - & - & - & 2 \\
\hline Adıyaman & - & - & - & - & - & 1 & 1 & - & - & - & 2 \\
\hline Muğla & - & - & - & - & 1 & - & - & 1 & - & - & 2 \\
\hline Diyarbakır & - & - & - & - & - & - & 1 & - & - & - & 1 \\
\hline Bolu & - & - & - & 1 & - & - & - & - & - & - & 1 \\
\hline Malatya & - & - & - & - & - & 1 & - & - & - & - & 1 \\
\hline Sivas & - & - & - & - & - & - & 1 & - & - & - & 1 \\
\hline Karabük & - & - & - & 1 & - & - & - & - & - & - & 1 \\
\hline Samsun & - & - & - & - & - & - & 1 & - & - & - & 1 \\
\hline Batman & - & - & - & - & 1 & - & - & - & - & - & 1 \\
\hline Ağrı & - & - & - & - & 1 & - & - & - & - & - & 1 \\
\hline Kastamonu & - & - & - & - & - & - & 1 & - & - & - & 1 \\
\hline Manisa & - & - & - & - & - & - & - & - & 1 & - & 1 \\
\hline Uşak & - & - & - & - & - & - & - & 1 & - & - & 1 \\
\hline Tekirdağ & - & - & - & - & - & - & - & - & 1 & - & 1 \\
\hline Yalova & - & - & - & 1 & - & - & - & - & - & - & 1 \\
\hline Türkiye geneli yıl bazında toplam & - & 5 & 3 & 37 & 21 & 20 & 44 & 28 & 23 & 5 & 186 \\
\hline
\end{tabular}


halk toplam 35 kişinin yaşamını yitirdiği belirtilmektedir (International Crisis Group, 2018, s. 5).

2018 yılında yaşanan toplumsal olay sayısı 28'e düşerken; 2019 yılında 23'e düşmüştür. 2017-2020 y1lları arasında Türkiye' de bulunan Suriyeli mültecilerin sayısında dalgalanmalar görülse de 3,5 milyonu aşmıştır. Türkiye'de bulunan Suriyeli mültecilerin sayısının 3588054 kişiye ulaştığı 2020 yılının ilk altı ayında ise sadece 5 olay yaşanmıştır. Çin Halk Cumhuriyeti' de Wuhan şehrinde Aralık 2019'da ortaya çıkan ve dünyaya yayılan pandemi süreci coronavirüs (Covid-19) nedeniyle Türkiye'de uygulanan tedbirlere bağlı olarak 2020 yılında toplumsal olay sayısında düşüş olduğu söylenebilir.

En fazla olayın görüldüğü Şanlıurfa'da, 2011-2020 yılları arasında toplam 25 toplumsal olay yaşanmıştır. Şanlıurfa' da 2015 yılı ve 2017 yılında altışar olay olmak üzere toplam 12 olay gerçekleşmiştir. 2018 yılında ise 5 toplumsal olay meydana gelmiştir (Tablo 5). Yaşanan olay sayısı bakımından ikinci sırada yer alan İstanbul'da toplam 19 toplumsal olay yaşanmıştır. İstanbul'da 2018 yılında 8 olay meydana gelmiştir. Konusu Suriyeli mülteciler olan toplumsal olaylar açısından bu sayı aynı zamanda 2011-2020 yılları arasında Türkiye'de bir yıl içerisinde ve aynı ilde gerçekleşmiş olan en yüksek düzeydir.

Yaşanan olay sayısı bakımından üçüncü sırada bulunan Gaziantep'te 2011-2020 yılları arasında toplam 17 toplumsal olay yaşanmıştır. Gaziantep'te yıl bazında en fazla olayın gerçekleştiği 2014 yılında 7 olay yaşanmıştır (Tablo 5). AFAD verilerine göre 2014 yılında 427138 kişiyle en fazla Suriyeli sığınmacı Şanlıurfa ilinde bulunurken; Gaziantep'te 326333 sığınmacı bulunmaktadır (AFAD 2020). Gaziantep'te yaşanan toplumsal olayların fazla olmasında, Suriyeli sığınmacı nüfusun oransal olarak yoğunluğunun etkili olduğu söylenebilir (Şekil 6).

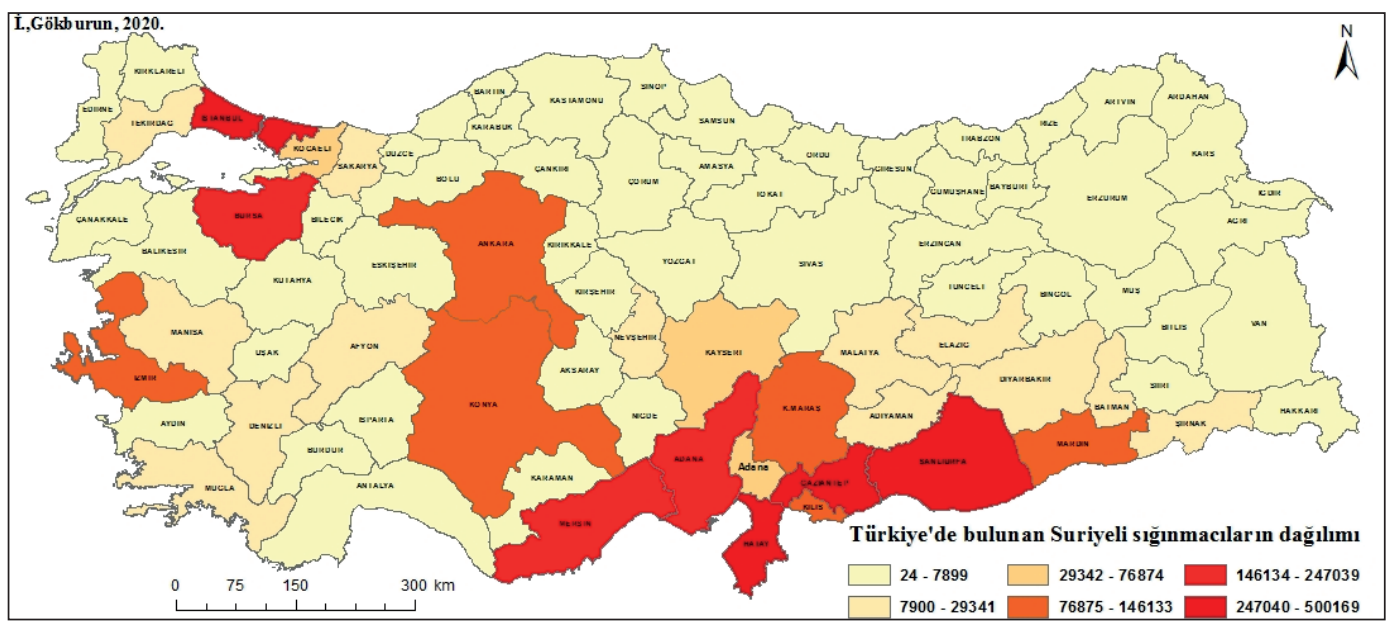

Şekil 4: Suriyeli Mültecilerin İl Bazında Dağılımı (2020).

Figure 4: Distribution of Syrian Refugees by Province (2020).

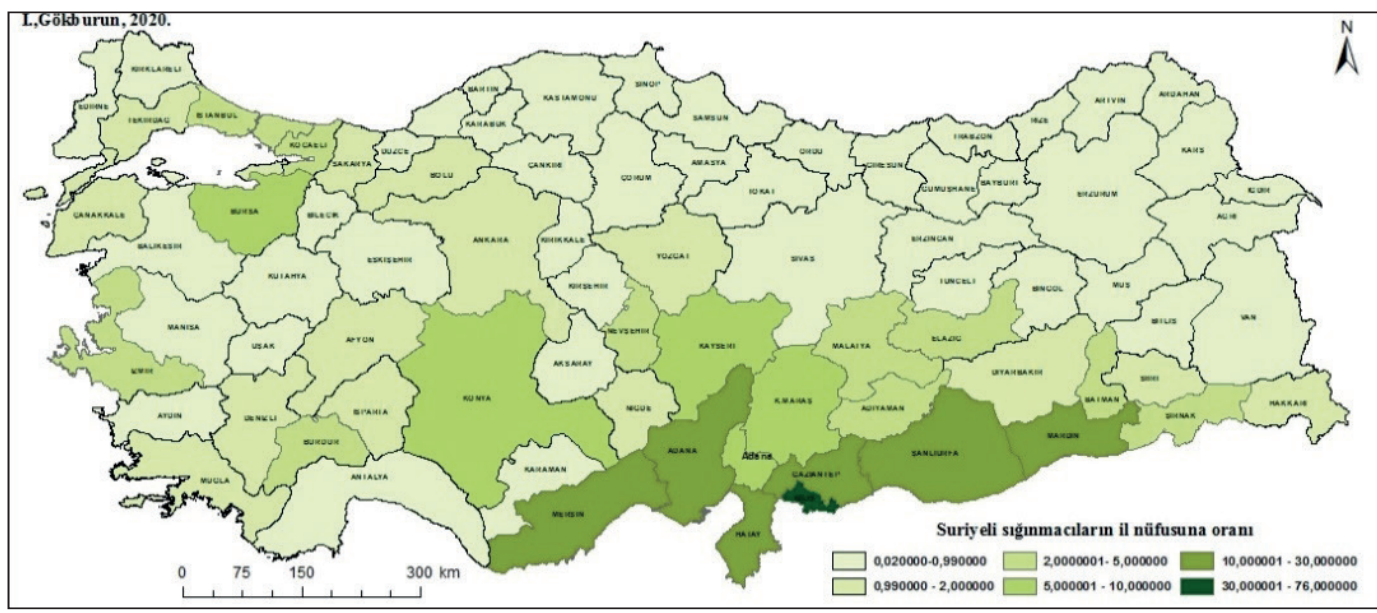

Şekil 5: Suriyeli Mültecilerin II Nüfusuna Oranı (\%)

Figure 5: The Ratio of Syrian Refugees to the Province Population (\%). 


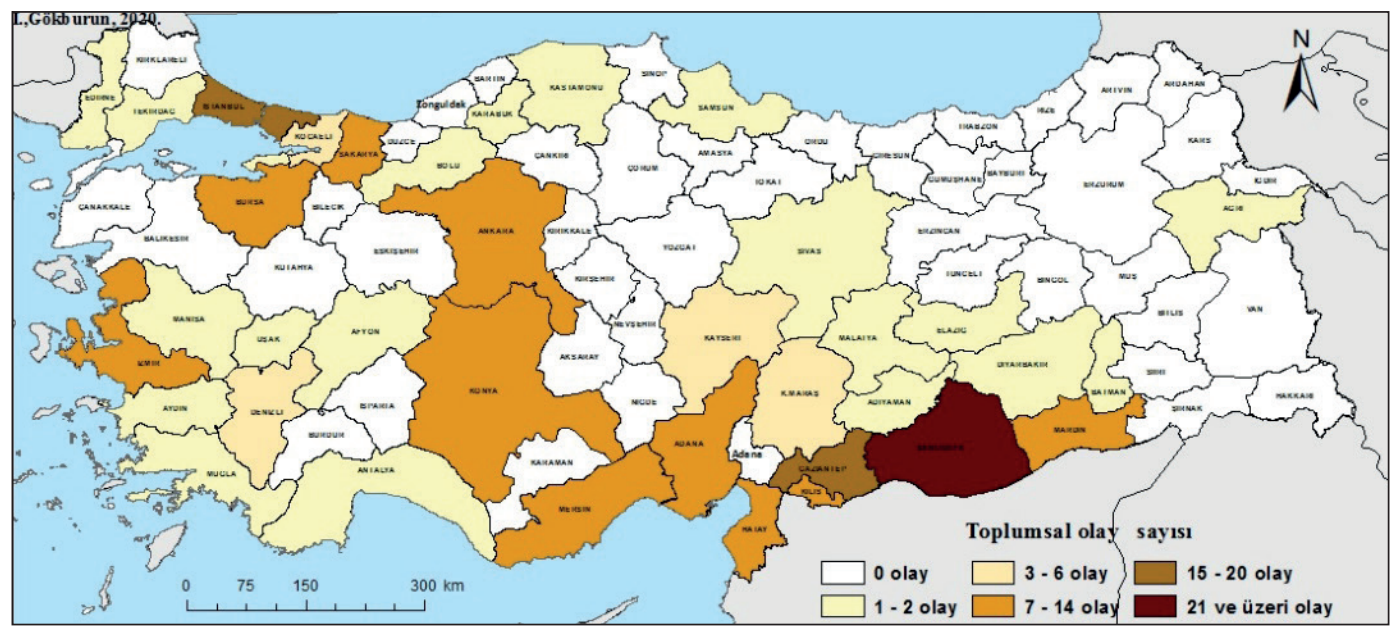

Şekil 6: Suriyeli Mülteciler ile Ev Sahibi Halk Arasında Meydana Gelen Toplumsal Olayların İ Bazında Dağılımı (2011-2020).

Figure 6: Distribution of Social Incidents by Province Occurring Between Syrian Refugees and Host People (2011-2020).

2014 y1linda toplam 4 olayla en fazla toplumsal olayin yaşandığı Hatay ilinde, Suriyeli sığınmacı nüfus 198050 kişidir. $\mathrm{Bu}$ dönemde Suriyeli sığınmacı sayısının en fazla olduğu Şanlıurfa ilinde 427138 kişi bulunmaktadır. Aynı dönemde Ankara, Kilis, Kahramanmaraş, Mardin ve Kayseri illerinde 3'er kez toplumsal olay yaşanmıştır. 2014 yılında sadece 2 toplumsal olayın yaşandığ gerçekleşmiştir. $\mathrm{Bu}$ dönemde Türkiye genelinde yaşanan toplumsal olayların 1/3'i Şanlıurfa'da meydana gelmiştir. 2014 yılında 7 toplumsal olayın yaşandığ 1 Gaziantep'te 2015 yılında hiçbir olay yaşanmazken; 2016 yılında 4 olay meydana gelmiştir. 2019 yılı ve 2020 yılında ulaşmış olduğumuz ilk altı aylık dönem verilerinde herhangi bir toplumsal olayın yaşanmadığı tespit edilmiştir.

Ankara, İzmir ve Adana illerinde 2011-2020 y1lları arasında her üç ilde de il bazında toplam 9'ar tane toplumsal olay yaşanmıştır. Hatay, Konya, Mersin, Bursa illerinde ise her ilde 8 toplumsal olay gerçekleşmiştir. Kilis, Mardin ve Sakarya illerinde toplam 7 olay yaşanmıştır. Kahramanmaraş'ta 6, Kayseri 5, Denizli 4 ve Kocaeli'nde 2 olay yaşanmıştır. Suriyeli nüfusun yoğunlaştığ 7 farklı ilde ikişer olay meydana gelirken; 13 ilde ise birer kez olay yaşanmıştır (Şekil 7) Toplumsal olayların il bazındaki dağılımı ile Suriyeli mülteciler il bazındaki dağılımı ile paralel bir seyir izlediği gözlenmektedir.

Araştırma kapsamında ulaşılan bu bulgular Türkiye'deki Suriyeli mülteciler ile ev sahibi halk arasında meydana gelen toplumsal olayların dağılımı konusunda önemli bilgiler sunmaktadır. Gazetelere yansıyan toplumsal olayların içeriğine dair bazı örneklerin sunulması; olaylara neden olan faktörlere ve olayların nasıl sonuçlarına dair açıklık getirebilir. Söz konusu bu örnek haberler; "toplumsal olay" kavramını ve araştırma verilerinin içeriğini daha belirginleştireceği düşünülmektedir. Konuyla ilgili örnek içeriklerden biri Hürriyet Gazetesi'nde 22.08.2017 tarihinde “Konya'da tehlikeli gerginlik” başlı̆̆ altında sunulmuştur: "Konya'nın Karapınar İlçesi'nde dün taciz iddiasıyla Suriye uyruklu 1 kişinin öldüğü, 1 kişinin de yaralandiğı kavganın ardından bugün de gerginlik yaşandl. Sosyal medya üzerinden örgütlenen yüzlerce kişi, önce yürüyüş yaptı, ardından da Suriyelilerin kaldiğı ev ve işyerine saldırıp, ateşe vermeye çalıştı. Polisin, olaylar başladıktan hemen sonra Suriyelileri evlerinden tahliye etmesi, olası bir faciayı önledi... Illçede bugün saat 21.00 stralarında taciz olayı iddiastyla sosyal medya üzerinden örgütlenen yüzlerce kişi, Anıt Meydanı'nda toplanip, Suriyelileri istemedekilerini dile getirdi. Ardindan ilçede yürüyüs yapan kalabalık, İstiklal Marşı'nın okunmasının ardından polisin uyarısı üzerine dă̆ıldı. Ancak dağılan kalabalığın büyük bir bölümü Çetni Mahallesi'nde hasarlv ve yıkılma tehlikesi nedeniyle boşaltılan Suriyelilerin kaldĭ̆g sağllk ocağı binasina gitti. Polis, binanın çevresinden önlem alırken, Konya ve Ereğli'den de takviye çevik kuvvet ekibi sevk edildi. Öfkeli kalabalı̆̆ın dağllmaması üzerine TOMA'dan slkılan tazyikli su ile müdahale edildi. Bunun üzerine öfkeli kalabalık bu kez polise tepki gösterdi" (Hürriyet, 22.08.2017). Söz konusu bu haberde görüldüğü üzere bazı toplumsal olayların nedenini taciz iddiaları oluşturmaktadır. Gazetelere yansıyan haberlerde özellikle taciz kaynaklı olayların kısa sürede büyüyerek kontrolden çıktı̆̆ı gözlenmektedir. Gösterilerin bazılarının sosyal medya üzerinden örgütlenerek geliştiği basına yansıyan haberlerde görülmektedir. Bilgi kaynağı olarak basında veya sosyal medyada çıkan haberler, toplumda genel bir izlenim oluşturarak olası tepkilere zemin hazırlamaktadır. 


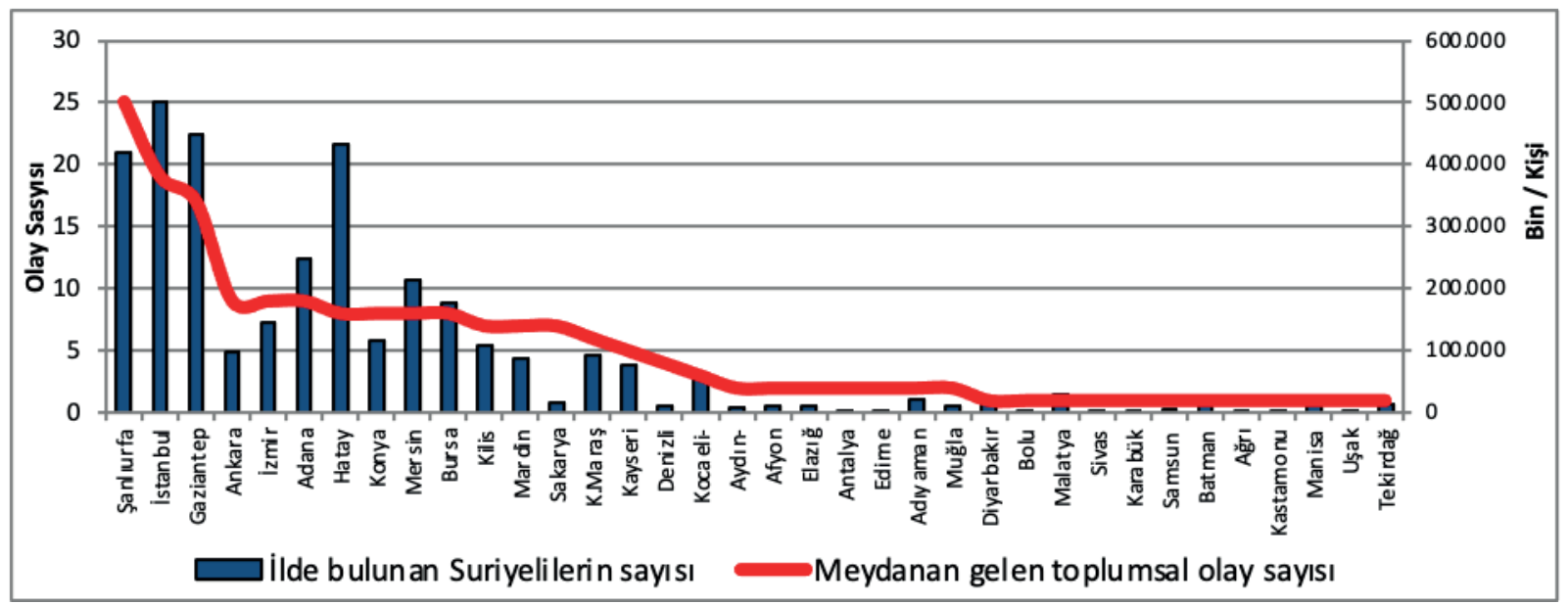

Şekil 7: Suriyeli Mülteciler ile Ev Sahibi Halk Arasında Meydana Gelen Toplumsal Olay Sayısının Dağılımı ve Bu Illerdeki Suriyeli Sayısı (2011-2020)

Figure 7: Distribution of the Number of Social Incidents Occurring Between Syrian Refugees and Host People and the Number of Syrians in These Provinces (2011-2020).

Araştırma kapsamında konuyla ilgili derlenen haber içeriklerini yansıtan bir başka örnek ise Milliyet Gazetesi'nde 14.07.2014 tarihinde; 'Kahramanmaraş'ta 'Suriyelileri istemiyoruz' yürüyüşünde olaylar çıktı” başlığı altında sunulmuştur.

"Kentte son günlerde Suriyelilerin suç işleyip huzursuzluğa yol açtığını ileri sürerek, kentten gitmeleri amactyla sosyal medyada örgütlenen çoğunluğu genç yaklaşık bin kişi, öğleden sonra Kıbrıs Meydanı'nda toplandı. Ellerinde Türk bayraklarlyla 'Suriyelileri istemiyoruz' sloganı atarak yürümek isteyen gruba polis izin vermedi. Uyarllara rağmen dağllmayan grup, Suriyelilerin kentten gitmesi için slogan atarak Trabzon Bulvarı'nı trafiğe kapattı. Daha sonra yürüyüşe geçen grubu durdurmak isteyen bazı vatandaşlar ile gruptakiler kavga etmeye başladl. Bölgeye gelen Emniyet Müdürü ... megafonla yapılanların kanunsuz olduğunu söyleyerek kalabalı̆̆ı dağılmasını istedi. Emniyet Müdürünü ... dinlemeyen ve islıklarla protesto eden grup ile yürüyüşe izin vermeyen polisler arasinda gerginlik yaşandl. Arbedede 1 'i polis, 2 kişi yaralandl. Arbedenin ardindan kalabalık gruplar halinde farkl bölgelere dağıldı. Gruptakiler, Kıbrıs Meydanı'nda park halindeki Suriye plakalı bir otomobilin camlarını kırarak zarar verdi. Başka bir grup ise Kent Parkı'nda önlerine çılkan ve içerisinde Suriye ailenin bulunduğu başka bir otomobile de saldırdı. Otomobilin camların kırarak, Suriyeli aileye saldıran kalabalık, polisin havaya ateş açmastyla bölgeden uzaklaştı" (Milliyet, 14.07.2014).

$\mathrm{Bu}$ haberde görüldüğü üzere toplumsal olaylara katılan grupların bazen sosyal medya üzerinde haberleşerek bir araya geldikleri görülmektedir. Söz konusu grupların kontrolsüz ve lidersiz bir şekilde toplanıyor. Önceden belirlenmiş herhangi bir grup liderinin olmadığı, grubun liderliğini grup içerisinde rastgele biri üstleniyor. Olayın akışına göre belirlenen grup liderinin herhangi bir kuruma, kuruluşa veya toplumsal gruba karşı sorumluluk taşımadığı söylenebilir. Bu nedenle toplumsal olayın yönetim sürecinde müzakere edecek, muhatap alacak biri bulunamadığ 1 için olayların kontrolden çıkarak kargaşaya ve çatışmaya dönüştüğü görülmektedir.

İstanbul Küçükçekmece ilçesinde gerçekleşen bir olay toplumda büyük bir infiale neden olmuştur. Olayla ilgili 6 gün sonra yetkililer tarafindan yapılan açıklamada bahse konu olayın bir yanlış anlaşılmadan kaynakladığı, vurgulanmıştır. "Valilik, "Olayın görgü tanı̆̆l, mağdur olduğu iddia edilen çocuk ve çocuğun anne-babasinın ifadelerinde 'konunun yanllş anlamadan kaynaklandı̆̆ ve herhangi bir kişiden şikayetçi olmadıklarını' beyan ettikleri anlaşılmış olup, adli ve idari tahkikatı sürdürülmektedir" dedi. ... Valilik, "Olayın görgü taniğı, mă̆dur olduğu iddia edilen çocuk ve çocuğun annebabasınin ifadelerinde 'konununyanlış anlamadan kaynaklandiğı ve herhangi bir kişiden şikayetçi olmadıklarını' beyan ettikleri anlaşılmış olup, adli ve idari tahkikatı sürdürülmektedir" dedi (Birgün, 30.06.2019).

Birçok farklı sebepten ev sahibi yerel halk ile Suriyeli mülteciler arasında, günlük hayatı olumsuz etkileyen sorunlar yaşanmaktadır. Bu örnekte görüldüğü üzere toplumsal olayların bir kısmı yanlış bir algı, bir fisıltının çevre yayılmasıyla ortaya çıktığı gözlenmektedir. Özellikle bazı durumlarda ev sahibi halk, mahalleli kimliği altında bir araya gelerek Suriyeli mülteciler şiddet içerikli tepkiler gösterdiği haberlere yansımıştır. 
Konuyla ilgili açıklamalar farklı gazetelerde yer almıştır: “Küçükçekmece'de Suriyeli bir kişinin "12 yaşındaki bir klz çocuğunu taciz ettiği” iddiası sosyal medyada "tecavüz"e dönüştü. Suriyeli çocuğu linç etmek çalı̧̧an mahalleli karakola yürümek isteyince 18 kişi gözaltına alındl. Gerçekte ise apartmandaki bir kişi çamaşır asarken düşürdüğ̈̈ mandalını Suriyeli çocuktan istemiş, çocuk da girdiği apartmandaki daireyi karıştırmıştı" (Sabah, 01.07.2019). Olayla ilgili ancak 6 gün sonra basına yansıyan bu açıklamalar mahallede kendine bir yaşam kurmuş mültecilerin zor anlar yaşamasına neden olduğu apaçık ortadır. Bahse konu bu durum toplumsal olayların önlenmesi için doğru bilgi akışının sağlanması ve halkın en erken şekilde bilgilendirilmesi büyük önem arz etmektedir.

Ev sahibi vatandaşlar ile Suriyeli mülteciler arasında yaşanan olayların genellikle bireysel darp, kavga hadisesinin büyümesiyle çıkmaktadır. Söz konusu olayların belirli bir şehirde kendine bir yaşam kurmuş olan Suriyelilerin, zor şartlarda kurmuş oldukları yaşam koşularını terk etmek zorunda kaldığı görülmektedir. "İzmir'in Torbalı ilçesinde, bir çocuğu dövdüğ̈̈ öne sürülen Suriyeli gruba, mahalle sakinleri sopa ve tirpanlarla saldirdl. I'i ăğr 30 kişinin yaralandı̆̆ı olay sonrası kentteki yaklaşık 500 kişilik Suriyeli grup mahalleyi terk etti" (Habertürk, 08.04.2017). Ancak zaman zaman taciz vakalarının da büyük çaplı toplumsal olaylara dönüştüğü görülmektedir. Toplumsal yaşamın huzuru ve diğer faaliyetlerini gerçekleştirebilmesi için öncelikle güven ortamının oluşturulması gerekmektedir (Karagöz, 2002, s.17). Güven duygusunun örselendiği, can güvenliğini emniyet altında hissedilmediği mekânlar, üzerinde yaşayanlarda bir an önce uzaklaşma duygusu doğurur. Bu durum insanı güvenli yerlere doğru göçe zorlar. Daha önemli bir husus ise asayiş ve güvenliğin sağlanmadığı yerlerde kaos ve korku ortamı oluşur. Bu nokta Türkiye'de bulunan Suriyeli mülteciler konusu; toplumsal huzurun sağlanması ve ülkenin, insanın güvenliği için her yönüyle ele alıp değerlendirilmesi gereken hassas bir konudur. Sonuç olarak, konuyla ilgili basına yansıyan haber metinlerinin içeriği irdelenerek toplumsal olayların ülke bazında dağılımı ortaya konulmuştur. Bahse konu toplumsal olayların mekânsal dağılımının bilinmesi, gelecekte yaşanması muhtemel olaylarla ilgili önlemler için öncelikler belirlenebilir.

\section{SONUÇ}

Göç olgusunun önemli sonuçlardan biri de toplumsal olaylardır. Göçün nedenleri ve sonuçları toplumsal yaşamı doğrudan etkilemektedir. Göç, mekân ve toplumsal doku arasında kuvvetli bir ilişki bulunmaktadır. Bu çalışmada 20112020 yılları arasında Türkiye'de farklı illerde yerel halk ve
Suriyeli mülteciler arasında yaşanan toplumsal olayların dağılımı ortaya konulmuştur. Herhangi bir olayın dağılım alanını bilmek, söz konusu o olay veya durumun nedenlerine ilişkin çok önemli bilgiler sunar.

Yaşanan her coğrafi olayın bir nedeni bulunmaktadır. Benzer nedenlerin, benzer koşullarda genellikle aynı sonuçları ortaya çıkardığı bilinmektedir. Ayrıca, bir coğrafi olayın veya durumun farklı yerlerde nasıl ortaya çıktığını anlamak ve açıklamak amacıyla diğer yerlerle karşılaştırmalar yapılır. Bu kapsamda araştırmanın bulgularında ortaya konulan Suriyeli mülteciler ile yerel halk arasında yaşanan toplumsal olayların sayısı ve dağılımı; olaylarının nedenine ilişkin önemli sonuçlara ulaşılmasını sağlamıştır. Araştırmada olayların neden bazı illerde yoğunlaştığı sorgulanmıştır. Olayların nedenlerine ilişkin bazı örnek içerikler açıklanmıştır.

Sosyal, siyasal ve ekonomik boyutuyla Türkiye'de bulunan Suriyeli mültecilerin durum, uyum sorunu ve güvenlik nedeniyle önemli bir meseleye dönüşmüştür. Suriye'de kargaşanın başladığ 2011 'den bugüne Suriyeli mültecilere ev sahipliği yapan Türkiye; uyguladığı politikalar, organizasyon kabiliyeti ve kriz yönetimi konusunda oldukça başarılı bir sonuçlar ortaya koymuştur. Ancak Türkiye'de barınan Suriyelilerin çözüm bekleyen birçok sorunu bulunmaktadır. Özellikle zaman zaman yaşanan 'toplumsal olaylar' dikkat çekmektedir. Sosyokültürel, ekonomik, ideolojik, siyasi ve coğrafi koşullara bağlı olarak ortaya çıkan toplumsal olaylar; bireyler arasındaki bazı asayiş olaylarının ötesinde toplumun genelini etkilemektedir. Sosyal çevrede yaşanan değişimlere bir tepki olarak ortaya çıkan 'toplumsal olaylar' birçok faktörün dâhil olduğu kapsamlı bir olgudur. Toplumsal olaylar doğru ve etkili bir şekilde yönetilmediği takdirde darp, linç kundaklama vb. şiddet eylemlerine dönüşmesi ihtimal dâhilindedir.

Bireysel nedenlerle ortaya çıkan bazı asayiş olaylarının taraflarından biri Suriyeli mülteci ise sorun birdenbire büyüyerek nasıl kitlesel, toplumsal olaylara dönüştüğü konuyla ilgili verilen haber örneklerinde açıkça görülmektedir. Bahse konu bu soruna farklı araştırmacılar tarafından dikkat çekilmektedir. Genel anlamda mülteciler ve göçmenler bir 'güvenlik' meselesi olarak ele alınmaktadır. Bu konu hakkındaki söylemler tehlike ve kriz merkezli bir algı oluşturmaktadır. Ayrıca, mülteciler, göçmenler, sığınmacılar dünyanın hemen her ülkesinde herhangi bir nedenle kriz ortamı oluşturmak, toplumsal olaylar çıkarmak isteyenler için her an provokasyonlara zemin oluşturacak kadar hassas bir konudur (Kolukırık, 2009, s.3). Suriyeli mülteciler meselesi Türkiye'de günlük hayatın bir parçası haline gelmiştir. Zaman 
zaman Suriyeliler konusunda kayg1 yaratacak toplumsal olaylar ve protestoların yaşandığı ve bu sürecin iyi yönetilemediği takdirde, yabancı düşmanlığının yayılması, nefret söyleminin saldırılara dönüşme ihtimali vurgulanmaktadır (Erdoğan, 2014, s.25).

Mülteciler, göçmenler, sığınmacılar bulundukları ülkelerde, yerel halkın muhtemel tepkileri nedeniyle provokasyonların şiddet içeren kitlesel eylemlere dönüşmesi ciddi güvenlik riskine dönüşebilir (Ağır ve Sezik, 2015, s. 117). Ayrıca Suriyeli mültecilerin kendi aralarında örgütlenerek birtakım hak taleplerinde bulunabilecekleri ifade edilmektedir. Suriye'de iç savaş uzadıkça güvenlik riskinin artması beklenmelidir. Türkiye'de bugüne kadar geçen süreçte çok büyük sosyal problemlerin yaşanmaması ülkenin sosyokültürel yapının toplumsal sorunları önleyebilme kabiliyetini göstermektedir (Orhan ve Gündoğar, 2015, s.8). Ancak Suriye'deki savaşın dokuzuncu yılına girdiği 2020 yılında Türkiye'deki Suriyelilerin sayısı giderek artıyor. Dolayısıyla konuyla ilgili Türkiye'nin sorumluluğu ve sorunları da artmaktadır.

Araştırmanın 'veri ve yöntem' kısmında izah edildiği şekilde "doküman analizi" tekniğiyle basına yansıyan haberlerin taranmasıyla ulaşılan verilerde; 2011-2020 yılları arasında farklı illerde toplam 186 toplumsal olayın yaşandığ tespit edilmiştir. Yıl bazında en fazla olayın yaşandığ 2017 y1lında 43 toplumsal olay gerçekleşmiştir. 2017 yılında Türkiye'de bulunan Suriyeli mültecilerin sayısı 3426786 kişi iken 2018 yılında Suriyeli mülteciler 3623192 kişiye yükselmiş̧tir. Türkiye'de bulunan Suriyeli mültecilerin sayısının artmasına rağmen olay sayısı düşmüştür. 2019 yılında ise konusu Suriyeli mülteciler olan toplumsal olay sayısı 23'e düşmüştür. $\mathrm{Bu}$ durum Türkiye için göç politikaları açısından oldukça önemli bir sonuçtur. 2020 yılında sadece 5 olay yaşanmış ancak daha önce vurgulandığı üzere pandemi sürecinin olağandışı durumu elbette ki verileri etkilemiştir. Bu noktada Türkiye'de, bulunan Suriyeli mülteciler ile ilgili süreç uzadıkça toplumsal olayların arttığı yönündeki beyanların gerçeği yansıtmadığı söylenebilir. Daha da önemlisi Türkiye'de farklı kentlerde Suriyeli mültecilere yönelik yaşanan toplumsal olayların genel anlamda göçmenler ve mültecilere yönelik bir yabancı düşmanlığından kaynaklanmadığ 1 söylenebilir.

Ev sahibi ülke vatandaşları ile Türkiye'de bulunan Suriyeli mülteciler arasında yaşanan toplumsal olayların \%80'inin 14 ilde meydana geldiği tespit edilmiştir. Suriyeli mültecilerin yoğun olarak bulunduğu illerde, herhangi bir sebep toplumsal olayların yaşanmasına yol açabilir. Olumsuz sonuçlara meydan vermemek için bu illerde önceden tedbirlerine alınması önerilmektedir.

Günümüz dünyasında yaşanan ve haber değeri taşıyan hemen her olayın içeriği hızlı bir şekilde yayılmaktadır. Toplumun genelini ilgilendiren sıra dışı olaylar daha da ön plana çımaktadır. Yaşanan olayların temel nedeni genellikle toplumun hassas olduğu konulardır. Özellikle cinayet, taciz/tecavüz iddiaları, darp olayları, işgücü rekabeti Suriyeli mültecilere karşı genel bir öfke patlamasına neden olduğu tespit edilmiştir. Bu tür konular Suriyelilere karşı misafirperver bir tutum sergileyenlerde dahi bir tepkiye yol açabilir. Ayrıca Suriyeliler, Türkiye'de toplumsal sorunların kaynağı olarak algılanabilir. Ev sahibi yerel halktan gelen tepkilere karşı Suriyelilerin kendilerini korumak için örgütlenerek hareket etme ihtimali Türkiye'de daha büyük sorunlara yol açabilir.

Türkiye'de yakın dönemde göçün yönetilmesi amacıyla yapılan yasal düzenleme ve oluşturulan kurumsal yapı; mülteciler konusunda daha pratik çözümler üretip uygulamaya geçirmiştir. Bu noktada mültecilerin müracaatları, kayıtları ve verilerinin güncellenmesi övgüye değer gelişmelerdir. Ancak toplumsal olayların önlenmesi için sorumlu kurumlar ve akademik camianın iş birliği içinde yapacağ 1 çalışmalara ihtiyaç duyulmaktadır. Çalışmamızda 2011 yılından itibaren Suriyelilerin dâhil olduğu basina yer alan toplumsal olaylar irdelenmiş ve genel değerlendirmeler yapılmıştır. $\mathrm{Bu}$ bağlamda konuyla ilgili sosyoloji ve kamu yönetimi gibi bilim dallarında incelemeler yapmış olmakla birlikte bu çalışma, coğrafi bakış açısıyla mekânsal dağılışın yer aldığı, çeşitli tematik haritalar, tablolar ve grafiklerle konunun görselleştirildiği bir coğrafi araştırmadır. Olayların idari, siyasi ve sosyolojik boyutu için kapsamlı araştırmalara ihtiyaç duyulmaktadır.

\footnotetext{
Bilgilendirilmiş Onam: Katılımcılardan bilgilendirilmiş onam alınmıştır. Hakem Değerlendirmesi: Dış bağımsız.

Yazar Katkıları: Çalışma Konsepti/Tasarım- Ö.S.D., İ.G.; Veri Toplama- Ö.S.D., İ.G.; Veri Analizi/Yorumlama- Ö.S.D., İ.G.; Yazı Taslağı- Ö.S.D., İ.G.; İçeriğin Eleştirel İncelemesiÖ.S.D., I.G.; Son Onay ve Sorumluluk- Ö.S.D., İ.G.

Çıkar Çatışması: Yazarlar çıkar çatışması bildirmemiştir.

Finansal Destek: Yazarlar bu çalışma için finansal destek almadığını beyan etmiştir.

Informed Consent: Written consent was obtained from the participants.

Peer-review: Externally peer-reviewed.

Author Contributions: Conception/Design of Study- Ö.S.D., İ.G.; Data Acquisition- Ö.S.D. İ.G.; Data Analysis/Interpretation- Ö.S.D., İ.G.; Drafting Manuscript- Ö.S.D., İ.G.; Critical Revision of Manuscript- Ö.S.D., İ.G.; Final Approval and Accountability- Ö.S.D., İ.G. Conflict of Interest: The authors have no conflict of interest to declare.

Grant Support: The authors declared that this study has received no financial support.
} 


\section{KAYNAKÇA/REFERENCES}

Ağır, O. ve Sezik, M. (2015). Suriye'den Türkiye’ye Yaşanan Göç Dalgasından Kaynaklanan Güvenlik Sorunları. Birey ve Toplum Dergisi, 5(9), 95-123.

Akgündüz, A. (1999). Osmanlı İmparatorluğu ve D1ş Göçler, 17831922. Toplum ve Bilim, 80, 144- 170 .

Ardıç Çobaner, A. (2015). Çocuk Hakları Bağlamında Suriyeli Mülteci Çocukların Haberlerde Temsili. Marmara İletişim Dergisi, 24, 27-54.

Ataman, H. (2014). Yazılı Basında Ayrımcı Söylem, Suriyeli Mülteciler. Medyada Nefret Söylemi ve Ayrımcı Dil Eylül-Aralık 2014 Raporu içinde. İstanbul: Hrant Dink Vakfi.

Bayram, Y. (2016). Yerelde Öteki Olmak: Suriyeli Mültecilerin Trabzon Yerel Gazetelerinde Söylemsel Temsili. Uluslararası Sosyal Araştırmalar Dergisi, 9(42), 416-1430.

Bernstein, M. (2005). Identity politics. Annual Review of Sociology, 31, 47-74.

Boztepe, V. (2017). Televizyon Haberlerinde Suriyeli Mültecilerin Temsili. Ankara Üniversitesi İlef Dergisi, 4(1), 91-122.

Buechler, M. (1995). New social movement theories. Sociological Quarterly, 36, 441- 464.

Can A. ve Taşçı U. (2016). Teoriler Işı̆̆ında Toplumsal Olayların Gelişimi ve Yönetimi. Fırat Üniversitesi Sosyal Bilimler Dergisi, 26(1), 151-170.

Canyurt, D. (2015). Suriye Gelişmeleri Sonrası Suriyeli Mülteciler: Türkiye'de Riskler. Akademik Bakış Dergisi Uluslararası Hakemli Sosyal Bilimler, 48, 127-146.

Çağlar, İ. ve Özkır, Y. (2015) Suriyeli mültecilerin Türkiye basınında temsili. (ed. K. İnat \& M. Ataman) Ortadoğu Yıllı̆̆ı içinde. İstanbul: Açılım Kitap.

Çakır, M. (2013). İnternet Haberciliğinde Yasadışı Göç Sorunu. Online Academic Journal of Information Technology, 4(12), 105-124.

Çetin, T. (2008). Bulgaristan'daki Soydaşlarımızın Türkiye'ye Göç Etme Süreçlerini Etkileyen Bazı Değişkenlerin İncelenmesi. Türk Dünyası İncelemeleri Dergisi, 8(1), 55-75.

Çoban Keneş, H. (2016). Metaforun Ayrımcı Hegemonyanın İnşasındaki Rolü: Suriyelilerin Haberleştirilmesinde Metafor Kullanımı. Gaziantep University Journal of Social Sciences, 15(2), 253-280.

Demir, O. Ö. (2015), Göç Politikaları, Toplumsal Kaygılar ve Suriyeli Mülteciler. Ankara: Global Politika ve Strateji Yayını.

Dinçer, O. B., Federici, V., Ferris, E., Karaca, S., Kirişçi, K. ve Çarmıklı, E.Ö. (2013). Suriyeli Mülteciler Krizi ve Türkiye Sonu Gelmeyen Misafirlik. Ankara: Brookings Enstitüsü \& Uluslararası Stratejik Araştırma Kurumu (USAK).

Karademir, D, Doğan, M. (2019). Suriyeli Mültecilerin Mekânsal Analizi: Şanlıurfa Örneği. Coğrafya Dergisi, (39), 111-124.

Doğanay, Ü. ve Çoban Keneş, H. (2016). Yazılı Basında Suriyeli 'Mülteciler': Ayrımcı Söylemlerin Rasyonel ve Duygusal Gerekçelerinin İnşası. Mülkiye Dergisi, 40(1), 143-184.

Ekici, H. (2019). Türk Toplumunda Suriyelilere Yönelik Algilanan Tehditler Ve Çözüm Önerileri. Sosyal Politika Çalışmaları Dergisi, 19(44), 695-730.
Erdoğan, M. M. (2014). Türkiye'deki Suriyeliler: Toplumsal Kabul ve Uyum Araştırması. Ankara: Hacettepe Üniversitesi Göç ve Siyaset Araştırmaları Merkezi.

Erdoğan, M. M. (2015). Türkiye'ye kitlesel göçlerde son ve dev dalga: Suriyeliler. M. Erdoğan \& A. Kaya (der.) Türkiye'nin Göç Tarihi: 14. Yüzyıldan 21. Yüzyıla Türkiye'ye Göçler içinde (315-347). İstanbul: Bilgi Üniversitesi Yayınları.

Erdoğan, M. M. (2019). Türkiye'deki Suriyeli Mülteciler. KonradAdenauer-Stiftung. https://www.kas.de/documents/283907/7339115/ T\%C3\%BCrkiye\%27deki+Suriyeliler.pdf/acaf9d37-7035-f37c4982-c4b18f9b9c8e?version=1.0\&t=1571303334464 Erişim Tarihi: 10.10.2020.

Göker, G. ve Keskin, S. (2015). Haber Medyası ve Mülteciler: Suriyeli Mültecilerin Türk Yazılı Basınındaki Temsili. Iletişim Kuram ve Araştırma Dergisi, 41, 229-256.

Güran Yiğitbaşı, K. (2016). Medya ve Mültecileri Sivil Toplum Üzerinden Okumak: Mülteci-Der Örneği. Marmara İletişim Dergisi, 25, 53-76.

İçduygu, A. ve Sirkeci, İ. (1999). Cumhuriyet Dönemi Türkiyessinde Göç Hareketleri. 75 Yılda Köylerden Şehirlere Kitabı İçinde, (249268). İstanbul, Tarih Vakfi Yayınları.

Karagöz, A. (2002). Suç Önleme Hizmetleri. Ankara: EGM.

Karataş, M. (2015). Türk yazılı basınında Suriyeli mülteciler ile halk arasındaki ilişkinin incelenmesi. Göç Araştırmaları Dergisi, 1(2), 112-151.

Karpat, K. (2017). Osmanlı'dan Günümüze Etnik Yapılanma ve Göçler. İstanbul: Timaş Yayınları.

Kolukırık, S. (2009). Mülteci Ve Sığınmacı Olgusunun Medyadaki Görünümü: Medya Politiği Üzerine Bir Değerlendirme. Gaziantep Üniversitesi Sosyal Bilimler Dergisi, 8(1), 1-20.

Lang, K., \& Lang, G. (1961). Collective Dynamics. New York: Crowell. McAdam, D., \% Snow, D. A. (1997). Social movements: Readings on their emergence, mobilization, and dynamics. (Eds. McAdam, ve Snow), Los Angeles: Roxbury.

McCarthy, J. (1999). Death and Exile The ethnic Cleansing of Otoman Muslims 1821-1922. New Jersey. The Darwin Pres.

Merriam, S. (1998). Qualitative research and case study applications in education. Revised and expanded from case study research in education. USA: JB Printing

Ongun, Ö. (2014). Uluslararası habercilik ve söylem: Türkiye'deki gazetelerin Suriye iç savaşını yansıtma biçimleri. Galatasaray Üniversitesi İletişim Dergisi, 20, 77-97.

Orhan, O. ve Gündoğar, S. Ş. (2015). Suriyeli Mültecilerin Türkiye ye Etkileri. Ankara: ORSAM Yayın1, Rapor No: 195.

Özdemir, F. ve Öner Özkan, B. (2016). Türkiye'de Sosyal Medya Kullanıcılarının Suriyeli Mültecilere İlişkin Sosyal Temsilleri. Nesne Psikoloji Dergisi, 4(8), 227-244.

Pandır, M., Efe, İ. ve Paksoy, A. (2015). Türk Basınında Suriyeli Sığınmacı Temsili Üzerine Bir İçerik Analizi. Marmara İletişim Dergisi, 24, 1-26.

Tarrow, S. (1994). Power in Movement: Collective Action, Social Movements and Politics. Cambridge: Cambridge UniversityPress. 
Tobler, W. R. (1970), A Computer Movie Simulating Urban Growth in The Detroit Region. Economic Geography, 46(2), 234-240.

Tunç, A.Ş. (2015). Mülteci Davranışı ve Toplumsal Etkileri:Türkiye'deki Suriyelilere İlişkin Bir Değerlendirme. Tesam Akademisi Dergisi, 2(2), 29-63.

Yıldırım, A., ve Şimşek, H. (2013). Sosyal Bilimlerde Nitel Araştırma Yöntemleri. Ankara: Seçkin Yayıncılık

GİGMa. (2020). Göç İdaresi Genel Müdürlüğü. https://www.goc.gov.tr/ gecici-koruma5638 Erişim tarihi: 01.06.2020.

GİGMb. (2020). Göç İdaresi Genel Müdürlüğ̈̈. https://www.goc.gov. tr/kurumlar/goc.gov.tr/YillikGocRaporlari/2013_yillik_goc_ raporu.pdf Erişim tarihi: 10.03.2020.

UNHCR. (2020). Birleşmiş Milletler Mülteciler Yüksek Komiserliği. https://www.unhcr.org/syria-emergency.html Erişim tarihi: 15.06.2020.

AFAD. (2020). Afet ve Acil Durum Yönetimi Başkanlığ1. https://www. afad.gov.tr/suriyeraporlari Erişim tarihi: 14.06.2020.
International Crisis Group, (2020). https://www.crisisgroup.org/tr/ europe-central-asia/western-europemediterranean/turkey/248turkeys-syrian-refugees-defusingetropolitan-tensions Erişim tarihi: 10.05.2020.

Hürriyet, 22.08.2017: https://www.hurriyet.com.tr/gundem/konyadatehlikeli-gerginlik-suriyeliler-evlerinden-tahliye-edildi-40557542 Erişim tarihi: 22.05.2020.

Milliyet, 14.07.2014: https://www.hurriyet.com.tr/gundem/ kahramanmarasta-suriyelileri-istemiyoruz-yuruyusunde-olaylarcikti-26800668 Erişim tarihi: 25.05.2020.

Birgün, 30.06.2019: https:/www.birgun.net/haber/valilik-ve-emniyettenkucukcekmece-aciklamasi-260287 Erişim tarihi: 20.05.2020.

Sabah, 1.7.2019: https://www.sabah.com.tr/gundem/2019/07/01/birmandal-uzerinden-tahrik Erişim tarihi: 16.05.2020.

Habertürk, 08.04.2017: https://www.haberturk.com/gundem/ haber/1454871-torbalidaki-kavga-sonrasi-suriyeliler-ayrildi Erişim tarihi: 05.04.2020. 
